\title{
Din Öğretimi Alan Öğretmenlerinin Sınıf ve Sınıf Yönetimi Algılarının Metaforlar Üzerinden İncelenmesi
}

\section{Examining the Classroom and Classroom Management Perceptions of Religious Education Teachers Through Metaphors}

Fatih ÇAKMAK ${ }^{1}$

\author{
${ }^{1}$ Dr. Öğretim Üyesi, Felsefe ve Din Bilimleri, İslami İlimler, Afyon Kocatepe Üniversitesi, \\ Türkiye, fcakmak@aku.edu.tr, (https://orcid.org/0000-0002-0333-3834)
}

Geliş Tarihi: 10.02.2021

Kabul Tarihi: 24.11.2021

Öz

Araştırmanın temel amacı, din öğretimi alan öğretmenlerinin sınıf ve sınıf yönetimiyle ilgili algılarını metaforlar üzerinden betimlemektir. Araştırmada nitel araştırma desenlerinden fenemenolojik (olgubilimsel) araştırma deseni kullanılmıştır. Araştırmanın verileri katılımcıların, "sınıf... gibidir / benzer; çünkü..." ve "sınıf yönetimi ... gibidir / benzer; çünkü..." cümlelerini tamamladıkları yarı yapılandırılmış bir form aracılığıyla toplanmıştır. Verilerin analizinde frekans, yüzde hesaplamaları ve içerik analizi çözümleme teknikleri kullanılmıştır. Araştırma katılımcıları 105 din öğretimi alan dersi öğretmeninden oluşmaktadır. Öğretmenler "sınıfla" ilgili 44 metafor geliştirmiştir. En çok kullanılan metaforlar, bahçe, sahne, aile, arı kovanı, ayna, topraktır. Öğretmenlerin sınıfı tanımlarken ürettikleri metaforlar 8 kavramsal kategoride toplanmıştır. Bu kategoriler, bireysel gelişim kaynağı, sevgi ve güven kaynağ 1 , şekillendiren / geleceğe yön veren ortam, zengin bir yaşam alanı, dikkatli ve yoğun bir çalışma alanı, aydınlatan ortam, bilgi kaynağı, keşif kaynağı olarak sınıftır. Öğretmenler "sınıf yönetimi" ile ilgili 57 metafor geliştirmiştir. En çok kullanılan metaforlar, orkestra yönetmek, aile yönetmek, devlet yönetmek, araba kullanmak, çiçek bakımıdır. Öğretmenlerin sınıf yönetimini tanımlarken ürettikleri metaforlar 6 kavramsal kategoride toplanmıştır. Bu kategoriler, ahenk / uyum içerisinde yürütülen bir sanat, yol gösteren / yetiştiren bir süreç, yönetim / otorite alanı, düzen / kontrol alanı, mücadele / sorun giderme alanı, hassas / risk alınan bir süreç olarak sınıf yönetimidir.

Anahtar Kelimeler: Din eğitimi, din öğretimi alan öğretmeni, metafor, sınıf, sınıf yönetimi.

\begin{abstract}
The main purpose of this study is to determine the perceptions of religious education teachers about classroom and classroom management through metaphors. In the research, phenomenological research pattern, which is one of the qualitative research patterns, is used. The data of the study are collected from the participants by semi-structured form, by completing those sentencess: "The classroom is ... like/ similar, because..." and "The classroom management is ... like/ similar, because..." Frequency, percentage calculations and content analysis techniques were used in the research. Research participants consist of 105 teachers of religious instruction. 105 teachers developed 44 metaphors about the classroom. The most used metaphors are: Garden, stage, family, beehive, mirror, earth. The metaphors that their teachers produced while describing the classroom were collected in 8 conceptual categories. These categories are the class as a source of personal development, a source of love and trust, an environment that shapes / shapes the future, a rich living space, a careful and intense work area, an enlightening environment, a source of information, and a source of discovery. 105 teachers developed 57 metaphors about classroom management. The most used metaphors are: Running an orchestra, running a family, running the state, driving a car, flower care. The metaphors that their teachers produced while
\end{abstract}


defining classroom management were collected in 6 conceptual categories. These categories are an art that is carried out in harmony / harmony, a process that guides / nurtures, management / authority area, order / control area, struggle / problem-solving area, class management as a sensitive / risk-taken process.

Keywords: Religious education, religious education teacher, metaphor, classroom, classroom management.

\section{GİRIŞ}

İnsanlık sürekli bir değişim ve gelişim içerisindedir. Bu değişim insanlığın yeryüzünde var oluş tarihinden itibaren bugünlere kadar ürettiği bilgi, tutum, beceri ve değerlerin kuşaklar aras1 aktarımıyla sağlanmıştır (Başar, 2013). Bu da eğitimle gerçekleşmiştir. Bu değişim ve gelişime uygun nitelikte insanlar yetiştirebilmenin en temel gereksinimi iyi bir eğitim sistemidir. Eğitim sistemi, yapısal açıdan yaklaşıldığında toplumsal ihtiyaçların karşılanması işleviyle ortaya çıkmış, temel ögesi ya da öznesi insan olan bir yapıdır (Şişman, 2016).

Eğitim sisteminin en işlevsel parçası okuldur. Okul, özel bir yerde, belli bir sürede, değişen öğrenci ve öğretmeni ile geniş bir çevreye hitap eden, faaliyetlerinin planlı ve programlı olarak yürütüldüğü, bireyin ve toplumun ihtiyaçları sonucu ortaya çıkmış sosyal bir kurumdur (Çalık, 2012). Okulların toplumsal hayatta temel bir rol oynamaları sonucunda, formal eğitim insan yaşamının önemli bir bölümünü kapsamaya başlamıştır (Çapri, Balcı ve Çelikkaleli, 2010).

Okullarda eğitim öğretim faaliyetlerinin gerçekleştĭgi bir yaşam alanı olarak sınıf (Aydın, 2005), eğitim sisteminin ilk ve temel basamağıdır. Sınıf, ortak bir geçmişe, değer yargılarına, ortak bir kültüre sahip, ilgileri, ihitiyaç ve yetenekleri birbirlerinden farklı olan öğrenenlerden meydana gelen toplumsal bir gruptur (Gökyer ve Doğan, 2016). Sinıfın temel unsurlarından birisi öğrencidir. Gereksinimleri, beklentileri, öncelikleri, hazırbulunuşluk düzeyleri, öğrenme hızları, öğrenme biçimleri, çalışma alışkanlıkları, tutumları, duyguları farklılık gösteren öğrencilerin yer aldığ 1 sınıf ortamında (Sarıtaş, 2006), çok çeşitli davranış biçimleri ortaya çıkar. Farklılıklar, bazı durumlarda sınıfın havasına hoş bir renk, güzel bir anı katarak olumlu bir etki yaratırken, bazı durumlarda ise sınıfin psikolojik, toplumsal ve duygusal yapısına zarar verebilmekte (Gökyer ve Doğan, 2016), yönetim ve kontrol edilme bağlamında bazı güçlüklerin ortaya çıkmasına sebep olabilmektedir. Sınıf içindeki yaşantıların, belirlenmiş kazanımlara uygun olarak gerçekleşmesi öğretim lideri olarak öğretmenin sorumluluğudur. $\mathrm{Bu}$ bağlamda temel sorumluluğu, belirlenen hedefler çerçevesinde öğrencilerde istenilen yönde davranış değiş̧ikliği meydana getirmek olan öğretmenin, bunu yerine getirebilmesi, iyi bir sınıf yönetimi bilgi ve becerisine sahip olmasına bağlıdır (Akın ve Koçak, 2007; Sönmez, 1994).

Sınıf yönetimi eğitim yönetiminin temel basamağıdır (Çalık, 2012). Bu anlamda iyi bir eğitim yönetimi iyi bir sınıf yönetimine bağlıdır (Başar, 2009). Sınıf yönetimi; öğretmen, öğrenci, program, içerik, zaman, mekân, teknoloji, yöntem arasında etkili bir uyum ve düzen oluşturmak suretiyle sınıfı, öğrenmeye elverişli bir ortama dönüştürmeye yönelik etkinliklerin tümüdür (Sarıtaş, 2000). Ayrıca sınıf yönetimi, sınıf kurallarının belirlenmesi, uygun bir sınıf düzeninin sağlanması, öğretimin ve zamanın etkili bir şekilde yönetilmesi ve öğrenci davranışlarının denetlenerek olumlu bir öğrenme ikliminin geliştirilmesi sürecidir (Çelik, 2008). Başka bir tanıma göre sınıf yönetimi, sınıf yaşamının bir orkestra gibi yönetilmesi, içinde öğrenmenin gerçekleştiği bir çevrenin oluşturulabilmesi için gerekli olanak ve süreçlerin, öğrenme düzeninin, ortamının, kurallarının sağlanması ve sürdürülmesidir (Başar, 2009). Özetle sınıf yönetimi, öğretimin etkili ve verimli olabilmesi için gerekli koşulların oluşturulmasını sağlayan tüm düzenleme ve etkinliklerle ilgilenir. Temel amac1, olumlu ve verimli öğrenme çevresi oluşturmak suretiyle öğrencilerin öğrenme hedeflerine ulaşmalarını sağlamaktır (Erden, 2014). Eğer bir sınıf etkili bir şekilde yönetilmezse, hedeflenen öğrenmeler de tam manasıyla gerçekleşmeyecektir (Arends, 2003'den Akt: Kars, 2007). 
Sınıf yönetiminin özellikleri düşünüldüğünde, sınıf yönetimi etkili bir sınıf liderliğini gerektirir ki o da sınıf yönetimi bilgi ve becerisine sahip kaliteli bir öğretmenle mümkündür. Sınıf yönetiminde başarı önemli oranda öğretimin yönetimine bağlıdır. Öğretmenin yönetim anlayışı sınıf yönetimini etkileyen en temel faktördür. Bu anlayış öğrencilerin ilgi, ihtiyaç ve beklentilerine, gelişim özelliklerine, yaşlarına ve sınıf seviyelerine göre farklılık göstermelidir. Öğrencilerin olumlu davranışlarının sürdürülmesi, olumsuz davranışlarının değiştirilmesi amaçlanır. Sınıf yönetimi, sınıfta düzenin sağlanması ve etkili öğretim olmak üzere iki boyut üzerinde odaklanır. Ayrıca toplumsal kültür, okul kültürü ve iklimi, ülkenin eğitim politikası da sinıf yönetimini etkiler (Çelik, 2008).

Öğretmenin kişilik özellikleri, çocuklara yönelik algısı, mesleki deneyimi, kullandığ1 öğretim yöntem ve teknikleri, öğretim stili ve öğrencilerden beklentileri çocukların davranışlarını olumlu veya olumsuz olarak etkileyebilir (Erdoğan, 2008). Eğitimin başarıya ulaşması ve istenilen verimin elde edilebilmesi için etkili sınıf yönetiminin kritik öğesi olan öğretmenin; sınıfta düzeni sağlaması, olumlu bir sınıf atmosferi oluşturması, etkili öğretim yöntem ve teknikleri kullanması gerekmektedir. Öğretim programlarının kalitesi, teknolojik imkânlar, sınıfların fiziki yapısı, okul binaları vs. eğitim-öğretimde başarının sağlanabilmesi için tek başına yeterli olmayacaktır. Eğitim-öğretim faaliyetlerinde başarılı olmak için sınıfın iyi bir şekilde yönetilmesi gerekmektedir (İlgar, 2000). Öğretmenlik mesleğinin gerektirdiği nitelikleri taşımayan bir öğretmenin etkili sınıf yönetimi davranışları göstermesi beklenemez (Turan, 2018).

Öğretmenler etkili ve aktif öğrenmenin gerçekleşmesi ya da öğretme sorumluluklarını yerine getirmek amacıyla sınıfı yönetmeye çalışırlar. Bu yönetme sanatı çok kolay bir iş de değildir. Zira öğretmen bir taraftan sınıfın fiziki olanaklarını en iyi şekilde kullanacak, eğitim öğretim faaliyetlerini planlayacak, sınıfta kullanacağı öğretim yöntem ve tekniklerini belirleyecek, etkileşimli bir sınıf ortamı yaratabilmek amacıyla eğitsel etkinlikleri gerçekleştirecek, nitelikli bir ders işleyecek, diğer yandan öğrenci davranışlarını kontrol edecektir. Sınıfı etkili biçimde yönetmek, bir ölçüde satranç oynamaya benzemektedir. Bir satranç oyuncusunun yaptı̆̆ gibi etkili öğretmen de en uygun hareketleri arka arkaya getirecek veya sinıftaki etkinlikleri usulüne uygun biçimde yürütecek ve en iyi sonucu elde etmeye çalışacaktır (Balay, 2003). Bu amaçla etkili sınıf yönetimi için öğretmen; sınıf ortamına tesir eden sınıf içi ve dışı etkenleri bilmeli, sınıf içinde olumlu öğrenci-öğrenci ve öğretmen-öğrenci etkileşimi yaratabilmeli, sınıfta etkili bir öğrenme ortamı oluşturabilmeli, öğrenmeyi sağlayacak davranış değiştirme yöntem ve tekniklerini iyi bilmelidir (Erden, 2014). Yine etkili sınıf yönetimi için öğretmen; plan hazırlamalı, iyi bir örgütlenme ve sorunları tahmin etme becerisine sahip olmalı, ilkelerine bağlı kalmalı, öğrencilerin kapasitelerine uygun öğrenme ortamları yaratabilmelidir (Balay, 2003).

Öğretmen, sınıfı yönetirken bazı sorunlar ortaya çıkabilir. İstenmeyen öğrenci davranışları her sınıf ortamında yaşanabilmektedir. Hatta öğretmenler sınıf içi eğitsel etkinlikler için kullanmaları gereken zamanın büyük bir kısmını istenmeyen davranışlarla mücadele ederek geçirmektedirler (İra, 2016). İstenmeyen davranışlar, sınıf ortamında eğitsel çabaları engelleyen, sınıf içi etkinliklerin yapılmasında aksamalara yol açan ve düzeni bozan davranışlardır (Özer, Bozkurt ve Tuncay, 2014). İstenmeyen davranış, aynı zamanda öğretmenin öğretimini, öğrencinin kendisinin ve diğerlerinin öğrenmesini engelleyen, öğrenme ortamını doğrudan ya da dolaylı olarak rahatsız edici olan, karışıklık yaratan davranıştır (Ercan, 2012). Buna göre istenmeyen davranışlar, eğitsel amaçların gerçekleşmesine engel olmakta ve sınıf üyelerini olumsuz yönde etkilemektedir.

Öğrenci davranışlarını istenmeyen davranış olarak tanımlayabilmek için dört temel ölçüt; kendisinin ve arkadaşlarının öğrenmelerine engel olması, kendisinin ve arkadaşlarının güvenliğini tehlikeye atması, okul araç-gereçlerine ya da arkadaşlarının eşyalarına zarar vermesi ve öğrencinin diğer öğrencilerle sosyalleşmesine engel olan davranışlar olarak belirtilmiştir (Ercan, 2012; Gül, 2018). Önem sırasına göre öğretmenler tarafından istenmeyen davranışlar 
davranış bilimcilere göre; saldırganlık, ahlaksızlık, otoriteye karşı gelme, sınıf içi saygısızlık, zamanı boşa geçirme olarak sıralanmaktadır (Ercan, 2012). Bazı istenmeyen davranış örnekleri olarak, öğrencilerin sınıfta bir şeyler yemeleri, gürültü yapmaları, itaatsizlik etmeleri, söz almadan konuşmaları, derse geç gelmeleri, yavaş olmaları, arkadaşlarını engellemeleri, düzensiz olmaları, ayakta dolaşmaları, sınıf eşyalarına zarar vermeleri, sürekli mazeret ileri sürmeleri, arkadaşlarına fiziksel şiddet uygulamaları, dikkat çekmeye çalışmaları, kılık-kıyafetlerine özen göstermemeleri, okul ve sınıf kurallarına uymamaları gibi davranışlar belirtilmektedir (Ercan, 2012; Gül, 2018).

İstenmeyen davranışlar çeşitli ölçütlere göre farklı açılardan sınıflandırılmaktadır. Sarıtaş (2000), sebep oldukları sonuçlar üzerinden istenmeyen davranışları kontrolsüz, aşırı kontrollü, planlı, amaçlı ve kasıtlı davranışlar olarak sınıflandırır. Öztürk (2002), sonuçlarına göre akademik etkinliklere, sosyal ilişkilere ve fiziksel donanım ve ortama zarar verici davranışlar olarak sınıflandırır. Korkmaz (2002), başkalarının haklarına saygısızlık, kendinin ya da diğerlerinin öğrenmesini engelleyici, yasal olmayan, öğretmenin otoritesine karşı koyucu, kendisinin veya diğer öğrencilerin güvenliğini tehdit eden fiziksel olarak tehlikeli, okulun, sınıfın, arkadaşlarının, öğretmenin araç-gereçlerine, eşyasına zarar verici davranışlar olarak sınıflandırır. Özdemir (2004) ise dersi bölen, dersin akışını bozan, derse ilgiyi azaltıcı, toplumsal beklentilere uygun düşmeyen, saldırganlık ve ahlaksızlık içeren davranışlar olarak sınıflandırır. İstenmeyen davranışların çok farklı nedenleri olabilir. $\mathrm{Bu}$ davranışlar fizyolojik çevre, aile, toplum, arkadaş çevresi, medya gibi okul dışı nedenler olabileceği gibi öğrenci özellikleri, eğitim programı, öğretim yöntem ve teknikleri, sınıf kurallarının belirsizliği, sınıfın fiziksel özellikleri, sınıf içi düzenlemeler ve öğretmenlerin olumsuz tutumları gibi okul içi nedenlerden kaynaklanıyor da olabilir (Gül, 2018).

Öğretmenler istenmeyen davranışlarla baş edebilmek için; derse hazırlıklı girmeli, derslere mutlaka olumlu bir tutum ve yüksek beklenti ile başlamalı, dersin bölümleri ya da etkinlikleri arasında geçişleri iyi yapmalı, öğrencileri derse girerken ve ders esnasında iyi gözlemlemeli, derslerde tutarlı davranışlar sergilemeli, sağlıklı bir disiplin planı yapmalı, istenmeyen davranışlara uygun müdahale becerisine sahip olmalı, olaylar kontrolden çıkmadan önce doğru müdahale etmeli (mizah kullanmak gibi), öğrenciye karş1 mümkün olduğu kadar sakinliğini korumalı, sınıf yaşantılarıyla ilgili anekdotlar tutmalı, sınıfta yaşanan sorunları sınıfta bırakmalıdırlar (Çalık, 2012). Aynı zamanda sınıf içinde etkili öğrenme ortamı oluşturmak için planlı olmak, hazırlık yapmak, yönetimi planlamak, sınıfi iyi yönetmek, istendik davranışı pekiştirmek, göz teması kurmak, açık ve net yönergeler vermek, öğrenciye yapabileceği kadar sorumluluk vermek, sınıf içinde etkileşim oluşturmak, öğrencilerin dikkatini çekmek, derse etkili bir şekilde hazırlanmak özellikle dikkat edilmesi gereken unsurlardır (Beytekin, 2016). Eğitsel etkinliklerin sağliklı bir biçimde sürdürülebilmesi, istenmeyen davranışların değiştirilmesi ve düzeltilmesi bilinçli bir sınıf yönetimi anlayışı gerektirir (Aydın, 2005). Bu anlamda öğretmenler sınıf yönetimi konusunda hazırlıklı ve deneyimli olmalıdırlar. Sınıf yönetimi konusunda gerekli bilgi, beceri ve tecrübeye sahip olmak hem istenmeyen davranışlarla baş etmede hem de sınıf ortamında beklenen kazanımlara ulaşmada öğretmenlere büyük avantajlar sağlar (Özyürek, 1997). İşte tüm bu nedeler öğretmenlerin alan bilgisi, pedagojik formasyon bilgi ve becerisi, genel kültür bilgisine sahip olmalarıla birlikte iyi bir sınıf yönetimi bilgi ve becerisine sahip olmalarını zorunlu kılmaktadır.

Sınıf yönetimi yaklaşımları geleneksel yaklaşım ve çağdaş yaklaşımlar olarak iki başlıkta incelenmiştir. Geleneksel yaklaşım, öğretmen, kural ve disiplin merkezli bir anlayışla, öğrencilerin kendileri için belirlenmiş kurallara kesinlikle uymak zorunda oldukları, sınıf ortamında disiplinin otoriter metotlarla sağlandığı yaklaşımdır (Uyanık Balat, 2013). Bu yaklaşımda öğretmen, kuralları belirlemekte, belirli bir içeriği aktif olarak öğrenciye sunmakta, öğrenci ise sorgulama olmaksızın pasif olarak kurallara uymakta ve dersi dinlemektedir (Baltac1, 2019). Öğrenci gelişimine uygun olan çağdaş yaklaşımda, sınıf yönetiminin merkezinde öğrenci olur ve geleneksel modelde geçerli olan otorite, yerini etkileşime 
bırakmıştır (Gündüz, 2001). Bu anlamda sınıf; gerçek yaşamın kendisi olarak, öğrenci, öğretmen, ders programları, eğitim ortamı gibi iç; okul, çevre ve aile gibi dış etmenlerin etkileştiği bir alan olarak kabul edilir (Aydın, 2009). Çağdaş yaklaşımlarda sınıf kuralları öğrenci ihtiyaçları çerçevesinde öğrencilerle birlikte belirlenir. Bu yaklaşımlar öğrenme odaklı, etkinlik temelli ve öğrenci katılımına olanak sağlayan yaklaşımlardır (Baltacı, 2019). Sınıfı çağdaş yaklaşımlara göre yönetmeye çalışan bir öğretmende bulunması gereken özellikler; insanlara karşı sevgi ve saygı dolu olmak, öğrencilerin bireysel farklılıklarının farkında olmak ve ona göre davranabilmek, öğrencilere nazik, ilgili ve samimi davranmak, hem iç hem de diş motivasyon kullanmak, herkese eşit davranmak, insan haklarına saygılı olmak, öğrencilerin eşit haklara sahip olduğunun farkında olmak, iletişim becerileri yüksek, değişime ve yeniliğe açık, davranışlarıyla iyi bir model olabilmek olarak ifade edilebilir (Moore, 2003).

Sınıf yönetimi modelleri tepkisel, önlemsel, gelişimsel ve bütünsel model olarak belirtilmiştir. (Balay, 2003; Başar, 1996; Beytekin, 2016; Çelik, 2008). Düzen sağlayıcı, ödül ceza türü etkinliklere odaklanan klasik bir sınıf yönetimi modeli olan tepkisel model, istenmeyen davranışa yönelik tepki gösterme eğilimiyle davranışın ve istenmeyen durumun düzeltilmesini amaçlar (Beytekin, 2016). Önlemsel model geleceği kestirme, sınıf ortamını ve uygulamalarını düzenleyerek istenmeyen davranış ya da durumun ortaya çıkmasını engellemeyi amaçlar. Önceden yapılan düzenlemeler istenen davranışlar için uygun ortamlar, kuralların oluşturulması ayrıntılı öğretim planı, sınıf içi düzenleme ve hazırlıklar ile istenmeyen davranışlar önlenmeye çalışılır (Beytekin, 2016). Gelişimsel model, öğrencilerin fiziksel, duygusal ve deneyimsel gelişimlerinin sınıf yönetiminde öğretmene rehberlik ettiği, sınıf yönetiminin öğretmen tarafından öğrencilerin gelişimsel özelliklerine göre düzenlendiği modeldir (Beytekin, 2016). Bütünsel model, sınıf yönetiminin diğer modellerinin davranış kalıplarının bir bütün olarak ele alındığı, istenen davranışların ortaya çıkabilmesi için uygun ortamların ve sınıf içi düzenlemelerin yapılabilmesi amacıyla genellikle önlemsel modelden, istenmeyen davranışları düzeltmek amacıyla gerektiğinde tepkisel modelden yararlanır. Aynı zamanda sınıf yönetimi etkinlikleri düzenlenirken öğrencilerin gelişim özellikleri dikkate alındığı için gelişimsel modelden de yararlanır (Beytekin, 2016).

Din eğitimi ve öğretimi özel bir alandır. Kendine has özellikleri olan, temelde iman, ibadet ve ahlâk alanlarını kapsayan bir bilgi aktarım sürecini ifade eder (Bilgin, 1983). Bu özel alanın temsilcisi olan din öğretimi alan öğretmenleri, hem öğretmenlik mesleğinin gerektirdiği yeterliliklere sahip olmalı hem de nitelikli bir formasyon bilgisi ve becerisi kazanmış olmalıdırlar. Burada ifade edilen formasyon bilgisi ve becerisi içerisinde en gerekli alanlardan biri sınıf yönetimi bilgisi ve becerisidir. Hatta din eğitimcisi için bu gereksinim diğer alanlardan çok daha fazladır. Çünkü din eğitimcisinin kazandırmaya çalıştığı din duygusu, kişiyi tüm yönleriyle etkileyen ve hayatı boyunca nasıl bir insan olarak yaşayacağı ya da nasıl bir kişiliğe sahip olacağını belirlemede değer taşımaktadır (Acuner ve Erbaş, 2016). Din eğitimcisi olmak bu anlamda büyük bir sorumluluktur (Aydın, 2005). Bu önemli ve zor sorumluluğun yerine getirilebilmesi için din öğretimi alan öğretmenleri etkili ve verimli bir öğrenme ortamı oluşturmaya çalışmalıdır. Bu amaçla öncelikle öğretmenlerin, sınıf kurallarını belirlemesi, uygun bir sınıf düzenini sağlaması, öğretimi ve zamanı etkili bir şekilde yönetmesi ve öğrenci davranışlarını denetleyerek sınıfta olumlu bir öğrenme iklimi oluşturması gerekmektedir. Zira öğrencide istendik değişme ve gelişmenin elde edilebilmesi, öğrencinin hedeflenen kazanımlara ulaşabilmesi için öğretmen gerekli koşulları sağlamalıdır. $\mathrm{Bu}$ da ancak din öğretimi alan öğretmenlerinin çağdaş sınıf yönetimi yaklaşım ve modellerine sahip olmasıyla mümkün olacaktır. Bu nedenle bu araştırma din öğretimi alan öğretmenlerinin sınıf ve sınıf yönetimi algılarını metaforlar aracılığı ile belirlemek istemektedir.

Bir düşünce ve görme biçimi olarak ifade edilen metafor (Morgan, 1998), bir düşünce malzemesi, insan kavrayışının bir şeklidir. Metafor sadece bir söz figürü değil aynı zamanda bir düşünce figürü olarak tanımlanmaktadır. (Lakoff ve Johnson, 2005). Metaforlar söylenmek isteneni daha az ve öz söylemeye, bir kavramla ilgili algıyı başka bir kavram ve o kavrama ait 
benzerlik üzerinden açıklamaya yaramaktadır. Ayrıca metaforlar aracılığıyla soyut olan tecrübeler somut olarak kavramsallaşır. Metafor kullanımı bireyi yaratıcı düşünmeye, üretkenliğe, hayal etmeye, anlamlandırmaya yönlendirir. Bir şeyin metafor olarak kabul edilebilmesi için üç sorunun cevaplanması gerekmektedir. 1. Metaforun konusu nedir? 2. Metaforun kaynağı nedir? 3. Metaforun kaynağından konusuna atfedilmesi düşünülen özellikler nelerdir? (Forceville 2002'den Akt: Aydın, 2010). Benzetme yapılan metaforda üç temel öge bulunur. Bunlar; benzeyen, benzetilen ve benzetilene ait özellik ya da benzetme yönüdür (Saban, 2004). "Allah katında İsa'nın misali Âdem 'in misali gibidir ki onu topraktan yaratt..." (Âl-i İmrân, 3/59). Metafor ögeleri açısından ayet incelendiğinde Hz. İsa benzeyen, Hz. Âdem kendisine benzetilen, topraktan yaratılma da benzetme yönüdür (Çakmak, 2020). İnsanlar ifade gücünü arttırmak amacıyla sıklıkla metafor kullanırlar (Aykaç ve Çelik, 2014). Sosyal bilimler araştırmalarında metaforlar önemli bir veri elde etme aracı olarak kullanılmaktadır (Yıldırım ve Şimşek, 2013). Ayrıca son yıllarda eğitim alanında da veri elde etmek amacıyla, anlaşı1mayan, anlaşılması zor olan konularda veya bazı kavram, alg1 ve tutumları daha anlaşılır olarak ifade etmede metaforlar kullanılmaktadır. $\mathrm{Bu}$ amaçla özellikle eğitim yönetiminde, müfredat geliştirme ve plânlamada; öğretim alanında da öğrenmeyi teşvik etme ve yaratıcı düşünceyi geliştirmede metaforlara başvurulmaktadır (Arslan ve Bayrakçı, 2006; Döş, 2010).

Alanyazında öğretmen, öğrenci, öğrenme, öğretme, okul, program vb. kavramlar üzerine gerçekleştirilmiş metaforik çalışmalar mevcuttur (Baker, 1991; Balcı, 1999; Cerit, 2008; Çakmak, 2021; Karateke, 2019; Martinez, Sauleda ve Huber, 2001; Nalçacı ve Bektaş, 2012; Saban, 2004; Tortop, 2013; Turhan ve Yaraş, 2013; Uzun ve Paliç, 2013; Yılmaz, Göçen ve Yılmaz, 2013). Alanyazında din öğretimi alan öğretmenlerinin sınıf ve sınıf yönetimi kavramlarına ilişkin metaforik algılarının incelendiği bir araştırmaya rastlanmamıştır. Bu yönüyle araştırma özgün bir çalışmadır. Ayrıca din öğretimi alanında sınıf yönetimi üzerine yapılan bazı çalışmalar bulunmaktadır. Bunlardan bazıları Uçar (2004), Kars (2007), Fakioğlu Bağc1 (2012), Şimşek (2012), Zengin (2013), Altıntaş (2017), Baltacı (2019) tarafindan gerçekleştirilmiştir. Uçar (2004), İlköğretim okulları II. kademedeki din kültürü ve ahlak bilgisi öğretmenlerinin sınıf yönetimi yeterliklerini Kayseri İli örnekliğinde araştırmıştır. Kars (2007), din kültürü ve ahlak bilgisi öğretmenlerinin kendi algılarına dayalı sınıf yönetimi yeterliklerini Konak İlçesi örneğinde araştırmıştır. Fakioğlu Bağc1 (2012), ilköğretim din kültürü ve ahlak bilgisi öğretmenlerinin sınıf yönetimi yeterliklerini Beykoz ilçesi örneğinde araştırmıştır. Şimşek (2012), din kültürü ve ahlak bilgisi öğretmen adaylarının sınıf yönetimi stratejilerine yönelik görüşlerini araştırmıştır. Zengin (2013), din kültürü ve ahlak bilgisi öğretmenlerinin eğitim öğretim yeterlik algılarını araştırmıştır. Altıntaş (2017), ilköğretim din kültürü ve ahlak bilgisi dersi öğretmenlerinin değer öğretiminde benimsedikleri sınıf yönetimi yaklaşımlarını araştırmıştır. Balc1 (2019), din dersi öğretmenlerinin sınıf yönetimi yaklaşımlarını etnometodolojik bir araştırma olarak çalışmıştır.

$\mathrm{Bu}$ araştırmanın amacı, din öğretimi alan öğretmenlerinin "sınıf" ve "sınıf yönetimi" kavramlarına ilişkin sahip oldukları algıları metaforlar aracılığıyla ortaya koymaktır. Bu amaç doğrultusunda aşağıdaki sorulara yanıt aranmıştır:

1. Din öğretimi alan öğretmenlerinin "sınıf" kavramına ilişkin sahip oldukları zihinsel imgeler (metaforlar) nelerdir?

2. Din öğretimi alan öğretmenlerinin "sınıf" kavramına yönelik ürettikleri metaforlar arasında cinsiyet ve kıdeme göre anlamlı farklılık var mıdır?

3. Din öğretimi alan öğretmenlerinin "sınıf" kavramına ilişkin sahip oldukları zihinsel imgeler (metaforlar) hangi kategoriler altında toplanabilir?

4. Din öğretimi alan öğretmenlerinin "sınıf yönetimi" kavramına ait sahip oldukları zihinsel imgeler (metaforlar) nelerdir?

5. Din öğretimi alan öğretmenlerinin "sınıf yönetimi” kavramına yönelik ürettikleri metaforlar arasında cinsiyet ve kıdeme göre anlamlı farklılık var mıdır? 
6. Din öğretimi alan öğretmenlerinin "sınıf yönetimi” kavramına ilişkin sahip oldukları zihinsel imgeler (metaforlar) hangi kategoriler altında toplanabilir?

\section{YÖNTEM}

\subsection{Araștırma Deseni}

Din öğretiminde öğretmenlerin sınıf ve sınıf yönetimiyle ilgili algılarını metaforlar üzerinden belirlemeye çalışan bu araştırmada nitel araştırma desenlerinden fenomenolojik (olgubilimsel) araştırma deseni kullanılmıştır. Fenomenolojik araştırma (olgubilim), tam anlamını kavrayamadı̆̆ımız, fakat bize tümüyle yabancı olmayan olguları araştırmayı amaçlayan çalışmalar için uygundur. (Yıldırım ve Şimşek, 2013). Kaynağını, felsefe ve psikolojiden alan bu araştırmalarda katılımcılar tarafından tanımlanmış şekliyle bir fenomenlenle ya da kavramla ilgili bireylerin yaşadığı deneyimler betimlenir. Bu betimlemeler söz konusu fenomenle ilgili çeşitli deneyimlere sahip bireylerin deneyimlerinin özüne ulaşma ve bu deneyimleri değerlendirmeyle sonuçlanır (Creswell, 2017)

"Gerçek nedir?" sorusuna cevap arayan bir yöntem olan fenomenoloji (olgubilim), tanımlayıcı bir araştırmadır. $\mathrm{Bu}$ yaklaşımda araştırmacı katılımcının kişisel (öznel) tecrübeleriyle ilgilenmekte, bireyin algılamalarını ve olaylara yükledikleri anlamları incelemektedir. Bu bağlamda genelleme yapmak değil, olguları tanımlamak önemlidir (Baş ve Akturan, 2008).

$\mathrm{Bu}$ araştırmada Din öğretimi alan dersleri öğretmenlerinin sınıf ve sınıf yönetimi kavramıyla ilgili algıları belirlenmeye çalışıldığı için olgubilim deseni tercih edilmiştir.

\section{2. Çalışma Grubu}

Olgubilim çalışmalarında olguyu deneyimleyen kişilerden olguyla ilgili ayrıntılı bilgi elde edilmeye çalışılır. $\mathrm{Bu}$ nedenle çalışma grubunda yer alan kişiler araştırılan olguyla ilgili deneyimleri bulunduğu için amaca yönelik seçilen kişilerdir. (Baker ve diğerleri 1992'den Akt: Onat Kocabıyık, 2015). Din öğretimi alan dersleri öğretmenlerinin sınıf ve sınıf yönetimi kavramıyla ilgili algılarını belirlemeye çalışan bu araştırmanın çalışma grubunu, gönüllülük esasına göre amaçlı örnekleme yöntemiyle belirlenmiş din öğretimi alan öğretmenleri oluşturmaktadır. Çalışma grubu ile ilgili tanımlayıcı bilgiler Tablo 1'de verilmiştir.

Tablo 1. Çalışma Grubundaki Öğretmen Adaylarıyla İlgili Kişisel Bilgiler

\begin{tabular}{llll}
\hline Değişken & Kategori & $\mathrm{N}$ & $\mathrm{F}(\%)$ \\
Cinsiyet & Kadın & 58 & 55,3 \\
\cline { 2 - 4 } Kıdem (Yı1) & Erkek & 47 & 44,7 \\
& $1-3$ yı1 & 20 & 19 \\
& $4-8$ yıl & 27 & 25,7 \\
& $9-14$ y11 & 18 & 17,1 \\
& $15-20$ yıl & 15 & 14,2 \\
& $21-27$ y1l & 17 & 16,1 \\
TOPLAM & 28 ve üstü & 8 & 7,6 \\
\hline
\end{tabular}

Tablo 1'e göre araştırma 105 din öğretimi alan öğretmeni ile gerçekleştirilmiştir. Bunların 58 'i (\%55,8) bayan, 46's1 (\%44,2) erkektir. Bu öğretmenlerin 20'si (\%19,2) 1-3, 26's1 (\%25) 48, 18'i (\%17,3) 9-14, 15'i (\%14,4) 15-20, 17'si (\%16,3) 21-27 ve 8'i $(\% 7,8)$ de 28 ve daha fazla yıldır ögretmen olarak görev yapmaktadır. Araştırmaya katılan öğretmenlerimizin kıdemlerine bakıldığında güzel bir dağılımın olduğu görülmektedir. Şöyle ki, araştırmada görüşlerini paylaşan öğretmenlerin yaklaşık \% 20'si olan 20'si 1-3 yıllık kıdeme sahiptir. Buna göre araştırmanın ortaya koyduğu sonuçlar, öğretmenliğe yeni başlamış ya da öğretmenlik 
mesleğinin ilk yıllarında olan öğretmenlerin, sınıf ve sınıf yönetimi algılarını ortaya koyduğu için önemlidir. Araştırmada görüşlerini paylaşan öğretmenlerin yaklaşı \%24'ü olan 25 'i ise öğretmenlikte 20 yılı aşkın hizmet vermekte olan gruptur. Araştırma yine tecrübeli öğretmen olarak ifade edilebilecek bu grubun sınıf ve sınıf yönetimi algılarını ortaya koyduğu için de önemlidir.

\subsection{Verileri Toplama Aracı}

Olgubilim yönteminde, yapılandırılmamış ya da yarı-yapılandırılmış görüşme teknikleri kullanılarak araştırılan olgu açıklanmaya çalışılır (Onat Kocabıyık, 2015). Araştırmaya katılan din öğretimi alan öğretmenlerine sınıf ve sınıf yönetimi kavramına ilişkin sahip oldukları algıları belirlemek amacıyla yarı yapılandırılmış bir form ulaştırılmıştır. Bu formda metafor hakkında kısa bir bilgi verildikten sonra öğretmenlik üzerine bir metafor örneği paylaşılmıştır. Sonra öğretmenlere "Sınıf .......... gibidir. Çünkü .............." ve "Sınıf yönetimi .......... gibidir. Çünkü .............." cümleleri verilerek, onlardan bu cümleleri tamamlamaları istenmiştir. Metaforlar aracılığıyla din öğretimi alan öğretmenlerinden çalışılan olgu/durum hakkında bir betimleme yapmaları istenmiş ve bu betimleme aracıllığı ile öğretmenlerin olgu/durum ile ilgili algıları ortaya konmaya çalışılmıştır. Araştırmada sınıf ve sınıf yönetimi kavramları ile ilgili metaforları belirlerken "gibi" kavramı metaforun konusu ile metaforun kaynağı arasındaki bağı ifade etmesi için kullanılırken, "çünkü” kavramı kullanılan metaforlar için bir gerekçe sunulmasını sağlamaktadır (Çakmak, 2021; Küçüktepe ve Gürültü, 2014). Form, din öğretimi alan öğretmenlerine online olarak ulaştırılmış, cevaplar da yine online olarak alınmıştır.

\subsection{Verilerin Analizi}

$\mathrm{Bu}$ araştırmada elde edilen veriler frekans, yüzde hesaplamaları ve içerik analizi yöntemleri kullanılarak çözümlenmiştir. İçerik analizi, veriden onun içeriğine ilişkin tekrarlanabilir ve geçerli sonuçlar çıkarmak üzere kullanılan bir araştırma tekniğidir (Koçak ve Arun, 2006). Sosyal bilimler alanında çokça kullanılan bu yöntemde, birbirine benzeyen veriler, belirli kavramlar ve temalar çerçevesinde bir araya getirilir, okuyucunun anlayabileceği bir biçimde organize edilir ve yorumlanır (Yıldırım ve Şimşek, 2013). İçerik analizi yapılırken veriler şu aşamalardan geçirilir:

1. Kodlama ve ayıklama aşaması; formlarda belirtilen metaforlar ve sebep cümleleri alfabetik olarak siralanır. Birden fazla metafor belirtilen ya da metafor verilip sebebi belirtilmeyen formlar bu aşamada elenir. Bu araştırmada 111 öğretmen formu doldurmuştur. $\mathrm{Bu}$ 111 öğretmene ait formun 3'ünde öğretmenler metafor belirtmemiş ya da metafor belirtmiş, sebebini belirtmemişlerdir. Bu sebeple bahsi geçen 3 form elenmiş ve değerlendirilmemiştir.

2. Örnek metafor imgesi derleme aşamasi; üretilen metaforlar, metaforun konusu, metaforun kaynağı ile kaynak ve konu arasındaki ilişki yönünden incelenir. Metafor kaynağı ile konusu arasında mantıklı ilişki kurulamayan formlar elenir. 111 adet formun 3'ünde öğretmenler metafor kaynağı ile konusu arasında mantıklı ilişki kurmadıkları için bu 3 form da elenmiş ve değerlendirilmemiştir.

3. Kategori geliştirme aşaması; Belirtilen metaforlar kaynak ve konu arasındaki ilişki bakımından incelenerek kategoriler oluşturulur (Çakmak, 2021; Egüz ve Öntaş, 2018).

$\mathrm{Bu}$ araştırmaya katılan 111 formun 6's1 yukarıda ifade edilen sebeplerle elenmiş, 105 formda din öğretimi alan öğretmenlerinin sınıf ve sınıf yönetimine dair geliştirdikleri metaforlar, kaynak ve konu arasındaki ilişki bakımından incelenmiş ve kategorize edilmiştir. Yapılan analizlerin güvenirliğinin sağlanması amacıyla iki alan uzmanı ile metafor ifadeleri üzerine değerlendirme görüşmesi yapılmıştır. Bu görüşme ile metaforların hangi kategorilere ait olduğunun belirlenmesinde görüş birliği ve görüş ayrılığ1 tespiti yapılmıştır. Güvenirlik katsayısı Şekil 1'deki güvenirlik katsayısı hesaplama formülü kullanılarak .91 olarak 
hesaplanmıştır. $\mathrm{Bu}$ değer genel olarak kabul gören güvenirlik katsayısı oranı olan .80 değerinden büyük olduğundan kazanım analizinin güvenilir olduğu söylenebilir (Baltacı, 2017).

Şekil 1: Kodlayıcılar arası uyum katsayısı hesaplama formülü (Baltacı, 2017).

$$
\text { Güvenirlik }=\frac{\text { Görüş Birliği }}{\text { Görüş Birliği }+ \text { Görüş Ayrılı̆ğ }}
$$

\section{BULGULAR}

\subsection{Sınıf Kavramı ile İlgili Üretilen Metaforlar}

Araştırmaya konu olan din öğretimi alan öğretmenlerinin "sınıf" kavramına yönelik geliştirdikleri metaforlar, metaforları temsil eden öğretmen sayıları ve yüzdeleri Tablo 2'de gösterilmiştir.

Tablo 2. Öğretmenlerin Sınıf Kavramına Yönelik Geliştirdikleri Metaforların Frekans ve Yüzde Dağılımları

\begin{tabular}{|c|c|c|c|}
\hline Metafor Siras1 & Metafor Ad 1 & $\mathrm{~N}$ & $\%$ \\
\hline 1 & Ağac & 2 & 1,90 \\
\hline 2 & Aile & 7 & 6,66 \\
\hline 3 & Aktar & 1 & 0,95 \\
\hline 4 & Akvaryum & 1 & 0,95 \\
\hline 5 & Arena & 1 & 0,95 \\
\hline 6 & Ar1 kovan1 & 4 & 3,80 \\
\hline 7 & Atölye & 2 & 1,90 \\
\hline 8 & Ay & 1 & 0,95 \\
\hline 9 & Ayna & 4 & 3,80 \\
\hline 10 & Bahçe & 23 & 21,90 \\
\hline 11 & Bitki & 1 & 0,95 \\
\hline 12 & Deniz & 1 & 0,95 \\
\hline 13 & Devlet & 1 & 0,95 \\
\hline 14 & Doğa & 2 & 1,90 \\
\hline 15 & Dünya & 2 & 1,90 \\
\hline 16 & Ev & 7 & 6,66 \\
\hline 17 & Evlat & 1 & 0,95 \\
\hline 18 & Fidan & 2 & 1,90 \\
\hline 19 & Futbol & 1 & 0,95 \\
\hline 20 & Gemi & 1 & 0,95 \\
\hline 21 & Gezegen & 1 & 0,95 \\
\hline 22 & Gökyüzü & 1 & 0,95 \\
\hline 23 & Havuz & 1 & 0,95 \\
\hline 24 & İnsan hafizası & 1 & 0,95 \\
\hline 25 & Kafile & 1 & 0,95 \\
\hline 26 & Kapalı kutu & 1 & 0,95 \\
\hline 27 & Karınca sürüsü & 1 & 0,95 \\
\hline 28 & Kütüphane & 1 & 0,95 \\
\hline 29 & Maden & 1 & 0,95 \\
\hline 30 & Ocak & 2 & 1,90 \\
\hline 31 & Okyanus & 1 & 0,95 \\
\hline 32 & Orkestra & 2 & 1,90 \\
\hline 33 & Orman & 2 & 1,90 \\
\hline 34 & Oyun hamuru & 1 & 0,95 \\
\hline 35 & Paylaşmak & 1 & 0,95 \\
\hline 36 & Pazar yeri & 1 & 0,95 \\
\hline
\end{tabular}




\begin{tabular}{llll}
\hline 37 & Sahne & 9 & 8,57 \\
38 & Sera & 1 & 0,95 \\
39 & Sofra & 1 & 0,95 \\
40 & Tarla & 3 & 2,85 \\
41 & Tohum & 1 & 0,95 \\
42 & Tomurcuk & 1 & 0,95 \\
43 & Toprak & 4 & 3,80 \\
44 & Yemek pişirmek & 1 & 0,95 \\
Toplam & & 105 & 100 \\
\hline
\end{tabular}
gibidir:

1. 105 öğretmen sınıf kavramına ilişkin 44 metafor üretmiştir.

2. Öğretmenlerin geliștirdikleri 44 metaforun 28 'i bir öğretmen tarafindan üretilmiştir. Bu da toplam metaforların \% 64'üne karşılık gelmektedir. Geriye kalan \% 36'ya yakın metafor, 2 ila 23 öğretmen arasında farklılaşan sayılarla temsil edilmektedir. Metafor başına düșen öğretmen sayısı ise 2,38'dir. Buna göre araştırma öğretmenlerin düşünce zenginliklerini ortaya koymaktadır.

3. Öğretmenlerin sınıf kavramını tanımlarken en çok kullandıkları metaforlar şunlardır: (1) bahçe, 23 öğretmen, \%21,90. (2) sahne, 9, \%8,57. (3) aile, 7, \%6,66. (4) ev, 7, \%6,66. (5) ar1 kovanı 4, \% 3,80. (6) ayna 4, \% 3,80. (7) toprak 4, \% 3,80.

4. 44 metaforun $15^{\prime} \mathrm{i}$ canlılarla, 29'u cansızlarla ilgilidir. Canlı varlıklarla ilgili metaforların 3'ü insan, 4'ü hayvanlar, 8'i bitkilerle ilgilidir. 3 insan ile ilgili metaforun 1'i meslekle ilgilidir. 29 cansız metaforun 27'si somut varlıklarla, 2'si soyut varlıklarla ilişkilidir.

Din öğretimi alan öğretmenlerinin sınıf kavramı ile ilgili ürettikleri metaforların cinsiyetlere göre dağılımı Tablo 3'te verilmiştir.

Tablo 3. Metaforların Cinsiyet Dağılımı

\begin{tabular}{|c|c|c|}
\hline $\begin{array}{l}\text { Kadın öğretmenler tarafından } \\
\text { üretilen metaforlar }\end{array}$ & $\begin{array}{l}\text { Erkek öğretmenler tarafindan } \\
\text { üretilen metaforlar }\end{array}$ & $\begin{array}{l}\text { Kadın ve erkek öğretmenler } \\
\text { tarafindan ortak üretilen } \\
\text { metaforlar }\end{array}$ \\
\hline $\begin{array}{l}\text { Ağaç, aktar, bitki, fidan, } \\
\text { gezegen, gökyüzü, insan } \\
\text { hafızası, kapalı kutu, } \\
\text { kütüphane, okyanus, orkestra, } \\
\text { orman, paylaşmak, sera, } \\
\text { yemek pisirmek. }\end{array}$ & $\begin{array}{l}\text { Akvaryum, arena, ay, deniz, } \\
\text { devlet, dünya, evlat, futbol, } \\
\text { gemi, havuz, kafile, karınca } \\
\text { sürüsü, maden, oyun hamuru, } \\
\text { pazar yeri, sofra, tohum, } \\
\text { tomurcuk. }\end{array}$ & $\begin{array}{l}\text { Aile, arı kovanı, atölye, ayna, } \\
\text { bahçe, doğa, ev, ocak, sahne, } \\
\text { tarla, toprak. }\end{array}$ \\
\hline
\end{tabular}

Din öğretimi alan öğretmenlerinin sınıf kavramı ile ilgili ürettikleri metaforların kıdemlerine göre dağılımı Tablo 4'te verilmiştir.

Tablo 4. Metaforların Kıdem Dağılımı

\begin{tabular}{|c|c|}
\hline $1-3$ y1l & $\begin{array}{l}\text { Aile, arı kovanı, atölye, ayna, bahçe (5), bitki, doğa, futbol, gezegen, gökyüzü, } \\
\text { karınca sürüsü, maden, orman, sahne, sera. }\end{array}$ \\
\hline $4-8$ y1l & $\begin{array}{l}\text { n1, bahçe (7), doğa, ev (4), fidan, gemi, kapalı kutu, orkestra, } \\
\text { eri, sahne (2), tohum, toprak (3). }\end{array}$ \\
\hline 9-14 y11 & yna, bahçe (2), deniz, ev (2), havuz, ocak, sahne (5). \\
\hline $15-20$ y1l & $\begin{array}{l}\text { a, bahçe (3), devlet, dünya, insan hafizası, kafile, okyanus, } \\
\text { uk, toprak. }\end{array}$ \\
\hline 21-27 y1l & $\begin{array}{l}\text { Ağaç (2), aile (2), atölye, ayna, bahçe (3), dünya, evlat, fidan, ocak, orkestra, } \\
\text { orman, oyun hamuru, tarla. }\end{array}$ \\
\hline 28 ve üstü & Aile, arı kovanı, bahçe (2), kütüphane, tarla (2), yemek pişirmek. \\
\hline
\end{tabular}


Öğretmenlerin geliştirdikleri metaforlar sınıf kavramına yönelik ortak özellikleri açısından incelenmiş, tespit edilen 44 metaforun sınıf olgusunu nasıl kavramsallaştırdığ belirlenmiş̧tir. $\mathrm{Bu}$ belirlemede öğretmenlerin geliştirdiği her metafor; metaforun konusu, metaforun kaynağ 1 ve metaforun konusu ile kaynağı arasındaki ilişki yönünden incelenmiş, her metaforun sınıf kavramına yönelik sahip olduğu bakış açısı / yaklaşım belli bir tema ile ilişkilendirilerek (örneğin, "Zengin bir yaşam alanı olarak sınıf” gibi) 8 farklı kavramsal kategori belirlenmiştir. Bu kategoriler Tablo 5 'te gösterilmiştir.

Tablo 5. Metaforların Kategorilere Dağılımı

\begin{tabular}{|c|c|c|c|}
\hline $\begin{array}{l}\text { Kategoriler } \\
(\mathrm{n}=8)\end{array}$ & $\begin{array}{l}\mathrm{f} \\
(\%)\end{array}$ & $\begin{array}{l}\text { Metaforlar } \\
(\mathrm{n}=44)\end{array}$ & $\begin{array}{l}\mathrm{f} \\
(\%)\end{array}$ \\
\hline 1. Bireysel gelişim & 38 & Bahçe 23, fidan 2, ocak 2, sera & 9 Metafor \\
\hline kaynağı olarak sınıf. & $\begin{array}{l}\text { Öğretmen } \\
\% 36,19\end{array}$ & $\begin{array}{l}\text { 1, bitki } 1, \text { tarla } 3 \text {, tohum } 1, \\
\text { tomurcuk } 1, \text { toprak } 4 .\end{array}$ & $\% 20,45$ \\
\hline 2. Sevgi ve güven & 17 & Aile 7 , devlet 1 , ev 7 , futbol & 5 \\
\hline kaynağı olarak sınıf. & $\% 16,19$ & takımı 1, paylaşmak 1 & $\% 11,36$ \\
\hline 3. Şekillendiren / & 15 & Atölye 2 , evlat 1 , oyun hamuru & 6 \\
\hline $\begin{array}{l}\text { Geleceğe yön veren } \\
\text { ortam olarak sinıf. }\end{array}$ & $\% 14,28$ & $\begin{array}{l}\text { 1, sahne } 9, \text { sofra } 1, \text { yemek } \\
\text { pişirmek } 1 .\end{array}$ & $\% 13,63$ \\
\hline $\begin{array}{l}\text { 4. Zengin bir yaşam } \\
\text { alanı olarak sınıf. }\end{array}$ & $\begin{array}{l}14 \\
\% 13,33\end{array}$ & $\begin{array}{l}\text { Aktar } 1 \text {, akvaryum } 1 \text {, deniz } 1 \text {, } \\
\text { doğa } 2 \text {, dünya } 2 \text {, gezegen } 1 \text {, } \\
\text { okyanus } 1 \text {, orkestra } 2 \text {, orman } 2 \text {, } \\
\text { pazar yeri } 1 \text {. }\end{array}$ & $\begin{array}{l}10 \\
\% 22,72\end{array}$ \\
\hline 5. Dikkatli ve yoğun & 6 & Arena 1, ar1 kovan1 4 , karınca & 3 \\
\hline $\begin{array}{l}\text { bir çalışma alanı olarak } \\
\text { sınıf. }\end{array}$ & $\% 5,71$ & sürüsü 1. & $\% 6,81$ \\
\hline 6. Aydinlatan ortam & 6 & Ay 1 , ayna 4, gökyüzü 1 . & 3 \\
\hline olarak sinıf. & $\% 5,71$ & & $\% 6,81$ \\
\hline 7. Bilgi kaynağı olarak & 5 & Ağaç 2, havuz 1, insan hafizas 1 & 4 \\
\hline sinif. & $\% 4,76$ & 1, kütüphane 1. & $\% 9,09$ \\
\hline 8. Keşif kaynağı olarak & 3 & Gemi 1, kapalı kutu 1, maden 1. & 3 \\
\hline sinif. & $\% 2,85$ & & $\% 6,81$ \\
\hline
\end{tabular}

Kategori 1. Bireysel gelişim kaynağ olarak sınıf. Tablo 5 incelendiğinde bu kategori 38 öğretmen $(\% 36,19)$ ve 9 metafor (\% 20,45) ile temsil edildiği görülmektedir. Bu kategorideki metaforlar; bahçe, fidan, ocak sera, bitki, tarla, tohum, tomurcuk, toprak olarak belirlenmiştir Aşağıda bu kategoriye ait metafor örnekleri verilmiştir.

\section{Bahçe:}

Sinıf bir bahçeye benzer. Çünkü orada çeşit çeşit tohumlar işlenir (Ö1, erkek, 1-3 ylllı ögretmen).

Sinıf bahçe gibidir. Çünkü çocuklar o bahçeye ekilen tohum gibi emek ister ve sonucunda istenilen ürün ortaya çıkar (Ö8, kadın, 4-8).

Sınıf bahçe gibidir. Çünkü orada doğal yapıları ile geliştirilmesi gereken özler vardır (Ö28, kadın, 21-27).

\section{Fidan:}

Sinlf bir fidana benzer. Çünkü fidan büyüyüp ürün veren ağaca dönüşür (Ö4, kadın, 21 27). 


\section{Ocak:}

Sinıf ocă̆a benzer. Çünkü sınıf ocă̆ından yetişen çocuklar sıcaklı̆ğ, bilgiyi, tecrübeyi, yaşamı ve zorluklarla mücadeleyi o ocakta o yuvada o kaynakta öğrenir. Kendisi de ileride bir ocak olur (Ö38, erkek, 21-27).

\section{Sera:}

Sinıf bir sera gibidir. Çünkü birer fide olan ögrencilerimizin gelişimi için optimum seviye oluşturulur (Ö̈44, kadın, 1-3).

\section{Bitki:}

Sinlf bir bitkiye benzer. Çünkü sulayıp beslerseniz yani çocuklara en önemli ders olan "Ahlak" dersi ile ilgili malzemeyi doğru verebilirseniz, işte bu, gelişim için en önemli can suyudur (Ö11,kadin, 1-3).

Kategori 2. Sevgi ve güven kaynağı olarak sınıf. Tablo 5 incelendiğinde bu kategori 17 öğretmen $(\% 16,19)$ ve 5 metafor $(\% 11,36)$ ile temsil edilmektedir. Bu kategorideki metaforlar; aile, devlet, ev, futbol takımı, paylaşmak olarak belirlenmiştir Aşağıda bu kategoriye ait metafor örnekleri verilmiştir.

\section{Aile:}

Sınıf bir aile gibidir. Çünkü sınıftakiler arasında paylaşım ve birlikte zaman geçirmekten kaynaklı bir sevgi bağl vardır (Ö48, erkek, 9-14).

Ev:

Sinıf ev gibidir. Çünkü seni güvende hissettirir (Ö20, kadın, 4-8)

\section{Paylaşmak:}

Sinıf paylaşmak gibidir. Çünkü ögrenciler sadece dersi değil insanlarla bir arada yaşamayı, birbirlerine destek olmayı, hayatı orada öğrenirler (Ö35, kadın, 4-8).

Kategori 3. Şekillendiren / Geleceğe yön veren ortam olarak sinıf. Tablo 5 incelendiğinde bu kategori 15 öğretmen $(\%$ 14,28) ve 6 metafor $(\% 13,63)$ ile temsil edilmektedir. Bu kategorideki metaforlar; atölye, evlat, oyun hamuru, sahne, sofra, yemek pişirmek olarak belirlenmiştir Aşağıda bu kategoriye ait metafor örnekleri verilmiştir.

\section{Atölye:}

Sinıf bir atölyeye benzer. Çünkü ögretmen ham olan öğrencileri burada işler, şekil verir, istenen / beklenen / sipariş verilen forma sokar (Ö42, erkek, 21-27).

\section{Oyun hamuru:}

Sinıf oyun hamuruna benzer. Çünkü orada öğrenciye istediğiniz şekli verebilirsiniz (Ö42, erkek, 21-27).

\section{Sahne:}

Sınıf sahne gibidir. Çünkü sinıfta heyecan ve mutluluk içerisinde sahnelenen bir gösteri ile meraklı seyircilerin geleceklerine yön vermeye çalışırsınız (Ö25, kadın, 4-8).

Kategori 4. Zengin bir yaşam alanı olarak sınıf. Tablo 5'e göre bu kategori 14 öğretmen $(\% 13,33)$ ve 10 metafor $(\%$ 22,72) ile temsil edilmektedir. Bu kategorideki metaforlar; aktar, akvaryum, deniz, doğa, dünya, gezegen, okyanus, orkestra, orman, pazar yeri olarak belirlenmiştir. Aşağıda bu kategoride yer alan metaforlara ilişkin örnekler verilmiştir. 


\begin{abstract}
Aktar:
Sinıf bir aktara benzer. Çünkü nasıl ki baharatların kokuları, tatları, renkleri farklı farklyysa, sinıftaki her bir öğrencinin de ilgi, yetenek, hayalleri, öğrenme biçimleri farklıdır, kendine özgüdür (Ö45, kadın, 9-14).
\end{abstract}

\title{
Deniz:
}

Sinıf deniz gibidir. Çünkü sinıf bazen durgun, bazen dalgall, bazen bereketli bazen slğ bir yaşam alanıdır (Ö58, erkek, 9-14).

\section{Doğa:}

Sınıf doğa gibidir. Çünkü orada farklı yaşantıları olan öğrenciler bir arada bulunur (Ö95, erkek, 1-3).

\section{Dünya:}

Sinıf bir dünya gibidir. Çünkü çok çeşitli kıtaları, okyanusları ovaları vardır (Ö103, erkek, 21-27).

\section{Orman:}

Sınıf orman gibidir. Çünkü içerisinde birbirinden farklı türler vardır (Ö103, erkek, 21 27).

\section{Pazar yeri:}

Sınıf bir pazar yeri gibidir. Çünkü orada farklı algllara, duygulara, isteklere vb. sahip bireyler vardır. Bu düşünce ile sinıflara girilmelidir (Ö105, erkek, 4-8).

Kategori 5. Dikkatli ve yoğun bir çalışma alanı olarak sınıf. Tablo 5 incelendiğinde bu kategori 6 öğretmen $(\%$ 5,71) ve 3 metafor $(\%$ 6,81) ile temsil edilmektedir. Bu kategorideki metaforlar; arena, arı kovanı, karınca sürüsü olarak belirlenmiştir. Aşağıda bu kategoriye ait metafor örnekleri verilmiştir.

\section{Arena:}

Sinıf bir arenaya benzer. Çünkü her an dikkatli olmal, her şeyi iyi gözlemlemeli. En ufak bir boşluk kabul etmez (Ö73, erkek, 15-20).

\section{Arı kovanı:}

Sinıf bir arı kovanı gibidir. Çünkü sinıfta öğretmenler hedefleri doğrultusunda ince çalışılar ve sonucu elde ederler (Ö96, erkek, 1-3).

Kategori 6. Aydınlatan ortam olarak sinif. Tablo 3'e göre bu kategori 6 öğretmen (\% 5,71) ve 3 metafor (\% 6,81) ile temsil edilmektedir. Bu kategorideki metaforlar; ay, ayna ve gökyüzü olarak belirlenmiştir. Aşağıda bu kategoriye ait metafor örnekleri verilmiştir.

\section{Ay:}

Sinıf ay gibidir. Çünkü bir aydınlık yüzü bir de karanlık yüzü vardır. Öğretmene düşen karanlıkta kalan ögrencileri aydınlı̆̆a çıkarmaktır (Ö5, erkek, 4-8).

\section{Gökyüzü:}

Sinıf bir gökyüzü gibidir. Çünkü ögrenciler yıldız öğretmenler ay olarak düşünüldüğünde ögrenciler ögretmenden aldlğg ışığl farklı farkl yandıtır (Ö43, kadın,1-3).

Kategori 7. Bilgi kaynağı olarak sinıf. Tablo 3'e göre bu kategori 5 öğretmen $(\% 4,76)$ ve 4 metafor (\% 9,09) ile temsil edilmektedir. Bu kategorideki metaforlar; 
ağaç, havuz, insan hafizası, kütüphane olarak belirlenmiş̧tir. Aşağıda bu kategoriye ait metafor örnekleri verilmiştir.

\section{Ağaç:}

Sinıf ă̆aç gibidir. Çünkü orada ă̆acın kök salması gibi çeşit çeşit bilgiler kök salar (Ö29, kadın, 21-27).

\section{Kütüphane:}

Sinlf bir kütüphaneye benzer. Çünkü orada bilinmeyenler ögrenilir (Ö21, kadın, 28 ve üstü).

Kategori 8. Keşif kaynağı olarak sinıf. Tablo 3'e göre bu kategori 3 öğretmen $(\% 2,85)$ ve 3 metafor (\% 6,81) ile temsil edilmektedir. Bu kategorideki metaforlar; gemi, kapalı kutu, maden olarak belirlenmiştir. Aşağıda bu kategoriye ait metafor örnekleri verilmiştir.

\section{Gemi:}

Sınıf bir gemi gibidir. Çünkü gemiyle çıktığımız yolda yeni diyarlar keşfederiz (Ö98, erkek, 4-8).

\section{Maden:}

Sinıf bir maden gibidir. Çünkü öğretmenin işçiliğiyle yeni değerler keşfedilir (Ö54, erkek, $1-3)$.

\subsection{Sınıf Yönetimi Kavramı ile İlgili Üretilen Metaforlar}

Araştırmaya konu olan din öğretimi alan öğretmenlerinin "sınıf yönetimi” kavramına yönelik geliştirdikleri metaforlar, metaforları temsil eden öğretmen sayıları ve yüzdeleri Tablo 6'da gösterilmiştir:

Tablo 6. Öğretmenlerin Sınıf Yönetimi Kavramına Yönelik Geliştirdikleri Metaforların Frekans ve Yüzde Dağılımları

\begin{tabular}{llll}
\hline Metafor Siras1 & Metafor Ad1 & N & $\%$ \\
\hline 1 & Ahtapot & 1 & 0,95 \\
2 & Aile yönetmek & 8 & 7,61 \\
3 & Antrenman sahas & 1 & 0,95 \\
4 & Araba kullanmak & 4 & 3,80 \\
5 & Araç motoru & 1 & 0,95 \\
6 & Arena & 1 & 0,95 \\
7 & Arı kovanı & 1 & 0,95 \\
8 & Arının bal yapması & 1 & 0,95 \\
9 & Ayar düğmesi & 1 & 0,95 \\
10 & Bahçıvanlık & 3 & 2,85 \\
11 & Baraj & 1 & 0,95 \\
12 & Bekçilik & 1 & 0,95 \\
13 & Beste & 1 & 0,95 \\
14 & Çiçek bakımı & 4 & 3,80 \\
15 & Çiftçilik & 2 & 1,90 \\
16 & Çobanlık & 2 & 1,90 \\
17 & Dantel örmek & 1 & 0,95 \\
18 & Deney yapmak & 1 & 0,95 \\
19 & Devlet yönetmek & 6 & 5,71 \\
20 & Doğa kanunları & 1 & 0,95 \\
21 & Dülgerlik & 1 & 0,95 \\
\hline
\end{tabular}




\begin{tabular}{|c|c|c|c|}
\hline 22 & Ekin ekmek & 1 & 0,95 \\
\hline 23 & Ev geçindirmek & 1 & 0,95 \\
\hline 24 & Fabrika yönetmek & 2 & 1,90 \\
\hline 25 & Futbol takımı yönetmek & 1 & 0,95 \\
\hline 26 & Galaksi & 1 & 0,95 \\
\hline 27 & Geleceğe yatırım yapmak & 1 & 0,95 \\
\hline 28 & Gemi kaptanlığ1 & 3 & 2,85 \\
\hline 29 & Girişimcilik & 1 & 0,95 \\
\hline 30 & Güneş & 2 & 1,90 \\
\hline 31 & Hayat & 1 & 0,95 \\
\hline 32 & Kelebek & 1 & 0,95 \\
\hline 33 & Kuş & 1 & 0,95 \\
\hline 34 & Labut çevirmek & 1 & 0,95 \\
\hline 35 & Makine & 1 & 0,95 \\
\hline 36 & Marangozluk & 1 & 0,95 \\
\hline 37 & Masa ayağ1 & 1 & 0,95 \\
\hline 38 & Meddahlık & 1 & 0,95 \\
\hline 39 & Müzik aleti çalmak & 1 & 0,95 \\
\hline 40 & Orkestra yönetmek & 18 & 17,14 \\
\hline 41 & Ocak yönetmek & 1 & 0,95 \\
\hline 42 & Renk spektrumu & 1 & 0,95 \\
\hline 43 & Saat & 1 & 0,95 \\
\hline 44 & Sahne yönetmek & 3 & 2,85 \\
\hline 45 & Sanat & 1 & 0,95 \\
\hline 46 & Seçim pusulası & 1 & 0,95 \\
\hline 47 & Seyislik & 1 & 0,95 \\
\hline 48 & Sinir sistemi & 1 & 0,95 \\
\hline 49 & Suya vurulan darbe & 1 & 0,95 \\
\hline 50 & Suya urgan bağlamak & 1 & 0,95 \\
\hline 51 & Terazi & 2 & 1,90 \\
\hline 52 & Toprak işlemek & 2 & 1,90 \\
\hline 53 & Ülke & 1 & 0,95 \\
\hline 54 & Ülke emniyeti & 1 & 0,95 \\
\hline 55 & Yolculuk & 1 & 0,95 \\
\hline 56 & Yönetmenlik & 2 & 1,90 \\
\hline 57 & Yumurta & 1 & 0,95 \\
\hline Toplam & & 105 & 100 \\
\hline
\end{tabular}
şunlardır:

1. 105 öğretmen sınıf yönetimi kavramına yönelik 57 metafor üretmiştir.

2. Öğretmenlerin geliştirdikleri 57 metaforun 42'si bir öğretmen tarafından üretilmiştir. $\mathrm{Bu}$ da toplam metaforların \% 73'üne karşılık gelmektedir. Geriye kalan \% 27'ye yakın metafor, 2 ila 18 öğretmen arasında farklılaşan sayılarla temsil edilmektedir. Metafor başına düşen öğretmen sayısı ise 1,84'tür. Buna göre araştırma öğretmenlerin düşünce zenginliklerini ortaya koymaktadır.

3. Öğretmenlerin sınıf yönetimi kavramını tanımlarken en çok kullandıkları metaforlar şöyle belirlenmiştir: (1) orkestra yönetmek 18 öğretmen, \%17,14. (2) aile yönetmek 8, \% 7,61. (3) devlet yönetmek 6, \%5,71. (4) araba kullanmak, 4, \% 3,80. (5) çiçek bakımı, 4, \% 3,80.

4. 57 metaforun 14 'ü canlılarla, 43’ü cansılarla ilgilidir. 14 canlı varlığa ait metaforun 10 'u insanlar 4'ü hayvanlarla ilişkilidir. İnsana ait 10 metaforun 10'u da mesleklerle ilgilidir. 43 cansız metaforun 30'u somut varlıklarla, 13'ü soyut varlıklarla ilgilidir. 
Din öğretimi alan öğretmenlerinin sınıf kavramıla ilgili ürettikleri metaforların cinsiyetlere göre dağılımı Tablo 7'de gösterilmiştir.

Tablo 7. Metaforların Cinsiyet Dağılımı

\begin{tabular}{|c|c|c|}
\hline $\begin{array}{l}\text { Kadın öğretmenler tarafından } \\
\text { üretilen metaforlar }\end{array}$ & $\begin{array}{l}\text { Erkek ögretmenler tarafindan } \\
\text { üretilen metaforlar }\end{array}$ & $\begin{array}{l}\text { Kadın ve erkek öğretmenler } \\
\text { tarafından ortak üretilen } \\
\text { metaforlar }\end{array}$ \\
\hline $\begin{array}{l}\text { Ahtapot, arının bal yapması, } \\
\text { ayar düğmesi, bekçilik, dantel } \\
\text { örmek, deney yapmak, ekin } \\
\text { ekmek, ev geçindirmek, } \\
\text { fabrika yönetmek, galaksi, } \\
\text { geleceğe yatırım yapmak, } \\
\text { girişimcilik, hayat, kuş, } \\
\text { makine, marangozluk, masa } \\
\text { ayağı, meddahlı, müzik aleti } \\
\text { çalmak, renk spektrumu, } \\
\text { terazi, toprak işlemek, ülke, } \\
\text { yumurta. }\end{array}$ & $\begin{array}{l}\text { Antrenman sahası, araç } \\
\text { motoru, arena, arı kovanı, } \\
\text { baraj, beste, çiftçilik, doğa } \\
\text { kanunları, dülgerlik, futbol } \\
\text { takımı yönetmek, kelebek, } \\
\text { labut çevirmek, ocak } \\
\text { yönetmek, saat, sanat, seçim } \\
\text { pusulası, seyislik, sinir } \\
\text { sistemi, suya vurulan darbe, } \\
\text { suya urgan bağlamak, ülke } \\
\text { emniyeti, yolculuk. }\end{array}$ & $\begin{array}{l}\text { Aile yönetmek, araba } \\
\text { kullanmak, bahçıvanlık, çiçek } \\
\text { bakımı, çobanlık, devlet } \\
\text { yönetmek, gemi kaptanlığı, } \\
\text { güneş, orkestra yönetmek, } \\
\text { sahne yönetmek, yönetmenlik. }\end{array}$ \\
\hline
\end{tabular}

Din öğretimi alan öğretmenlerinin sınıf kavramıla ilgili ürettikleri metaforların k1demlerine göre dağılımı Tablo 8'de gösterilmiştir.

Tablo 8. Metaforların Kıdem Dağılımı

\begin{tabular}{|c|c|}
\hline $1-3$ y1l & $\begin{array}{l}\text { Ahtapot, aile yönetmek (2), araba kullanmak (2), çiçek bakımı, çobanlık, dantel } \\
\text { örmek, galaksi, geleceğe yatırım yapmak, gemi kaptanlığı, marangozluk, müzik } \\
\text { aleti çalmak, orkestra yönetmek (2), seçim pusulası, sinir sistemi, terazi, } \\
\text { yolculuk. }\end{array}$ \\
\hline 4-8 y1l & $\begin{array}{l}\text { Aile yönetmek (5), antrenman sahası, araç motoru, arı kovanı, bahçıvanlık, } \\
\text { baraj, çiftçilik, deney, fabrika yönetmek, futbol takımı yönetmek, hayat, } \\
\text { kelebek, kuş, makine, meddahlık, orkestra yönetmek (4), sahne yönetmek, } \\
\text { toprak işlemek, ülke, yönetmenlik. }\end{array}$ \\
\hline 9-14 y1l & $\begin{array}{l}\text { Aile yönetmek, araba kullanmak (2), ayar düğmesi, çiçek bakımı, devlet } \\
\text { yönetmek, ekin ekmek, gemi kaptanlığı, güneş, orkestra yönetmek (4), sahne } \\
\text { yönetimi, sanat, suya urgan bağlamak, terazi, yönetmenlik. }\end{array}$ \\
\hline $15-20$ y1l & $\begin{array}{l}\text { Arena, bahçıvanlık, çiçek bakımı, çobanlık, devlet yönetmek (4), ev } \\
\text { geçindirmek, gemi kaptanlığı, orkestra yönetmek (2), saat, suya vurulan darbe, } \\
\text { toprak işlemek. }\end{array}$ \\
\hline 21-27 y11 & $\begin{array}{l}\text { Bekçilik, beste, çiçek bakımı, doğa kanunları, dülgerlik, fabrika yönetmek, labut } \\
\text { çevirmek, orkestra yönetmek (7), renk spektrumu, seyislik, ülke emniyeti. }\end{array}$ \\
\hline 28 ve üstü & $\begin{array}{l}\text { Arının bal yapması, bahçıvanlık, çiftçilik, devlet yönetmek, girişimcilik, güneş, } \\
\text { masa ayağı, orkestra yönetmek. }\end{array}$ \\
\hline \multicolumn{2}{|c|}{$\begin{array}{l}\text { Öğretmenlerin geliştirdikleri metaforlar sınıf yönetimi kavramına yönelik ortak özellikleri } \\
\text { açısından incelenmiş, tespit edilen } 57 \text { metafor sınıf yönetimi olgusunu nasıl kavramsallaştırdığ1 } \\
\text { belirlenmiştir. Bu amaçla öğretmenlerin geliştirdiği her metafor; metaforun konusu, metaforun } \\
\text { kaynağı me metaforun konusu ile kaynağ1 arasındaki ilişki yönünden incelenmiş, her metaforun } \\
\text { sınıf yönetimi kavramına yönelik sahip olduğu bakış açısı / yaklaşım belli bir tema ile } \\
\text { ilişkilendirilerek (örneğin, "Ahenk / Uyum içerisinde yürüttulen sanat olarak sınıf yönetimi" } \\
\text { gibi) } 6 \text { farklı kavramsal kategori oluşturulmuştur. Bu kategoriler Tablo 9'da gösterilmiştir. }\end{array}$} \\
\hline
\end{tabular}


Tablo 9. Metaforların Kategorilere Dağılımı

\begin{tabular}{|c|c|c|c|}
\hline $\begin{array}{l}\text { Kategoriler } \\
(\mathrm{n}=8)\end{array}$ & $\begin{array}{l}\mathrm{f} \\
(\%)\end{array}$ & $\begin{array}{l}\text { Metaforlar } \\
(\mathrm{n}=44)\end{array}$ & $\begin{array}{l}\mathrm{f} \\
(\%)\end{array}$ \\
\hline $\begin{array}{l}\text { 1. Ahenk / Uyum } \\
\text { içerisinde yürütülen bir } \\
\text { sanat olarak sınıf } \\
\text { yönetimi. }\end{array}$ & $\begin{array}{l}34 \\
\text { Öğretmen } \\
\% 32,38\end{array}$ & $\begin{array}{l}\text { Araba kullanmak } 4 \text {, beste } 1 \text {, } \\
\text { dantel örmek } 1 \text {, galaksi } 1 \text {, labut } \\
\text { çevirmek } 1 \text {, müzik aleti çalmak } \\
1 \text {, orkestra yönetmek } 18 \text {, renk } \\
\text { spektrumu } 1 \text {, sahne yönetmek } 3 \text {, } \\
\text { seyislik } 1 \text {, yönetmenlik } 2 \text {. }\end{array}$ & $\begin{array}{l}11 \text { Metafor } \\
\% 19,29\end{array}$ \\
\hline $\begin{array}{l}\text { 2. Yol gösteren / } \\
\text { Yetisstiren bir süreç } \\
\text { olarak sinıf yönetimi. }\end{array}$ & $\begin{array}{l}23 \\
\% 21,90\end{array}$ & $\begin{array}{l}\text { Arının bal yapmas } 1 \text {, } \\
\text { antrenman sahas } 1 \text {, bahçıvanlık } \\
3 \text {, çiçek bakımı } 4 \text {, çiftçilik } 2 \text {, } \\
\text { çobanlık } 2 \text {, dülgerlik } 1 \text {, ekin } \\
\text { ekmek } 1 \text {, geleceğe yatırım } \\
\text { yapmak } 1 \text {, gemi kaptanlığ } 13 \text {, } \\
\text { güneş } 2 \text {, marangozluk } 1 \text {, saat } 1 \text {. }\end{array}$ & $\begin{array}{l}13 \\
\% 22,80\end{array}$ \\
\hline $\begin{array}{l}\text { 3. Yönetim / Otorite } \\
\text { alanı olarak sinıf } \\
\text { yönetimi. }\end{array}$ & $\begin{array}{l}20 \\
\% 19,04\end{array}$ & $\begin{array}{l}\text { Aile yönetmek } 8 \text {, devlet } \\
\text { yönetmek } 6 \text {, ev geçindirmek } 1 \text {, } \\
\text { fabrika yönetmek } 2 \text {, ocak } \\
\text { yönetmek } 1 \text {, ülke } 1 \text {, ülke } \\
\text { emniyeti } 1 \text {. }\end{array}$ & $\begin{array}{l}7 \\
\% 12,28\end{array}$ \\
\hline $\begin{array}{l}\text { 4. Düzen / Kontrol } \\
\text { alanı olarak sınıf } \\
\text { yönetimi. }\end{array}$ & $\begin{array}{l}17 \\
\% 16,19\end{array}$ & $\begin{array}{l}\text { Ahtapot } 1 \text {, arı kovanı } 1 \text {, ayar } \\
\text { düğmesi } 1 \text {, baraj } 1 \text {, bekçi } 1 \text {, } \\
\text { deney yapmak } 1 \text {, doğa } \\
\text { kanunları } 1 \text {, futbol takımı } 1 \\
\text { yönetmek } 1 \text {, makine } 1 \text {, masa } \\
\text { ayağ1 } 1 \text {, meddahlık } 1 \text {, seçim } \\
\text { pusulas } 1 \text {, sinir sistemi } 1 \text {, terazi } \\
2 \text {,toprak işlemek } 2 \text {. }\end{array}$ & $\begin{array}{l}15 \\
\% 26,31\end{array}$ \\
\hline $\begin{array}{l}\text { 5. Mücadele / Sorun } \\
\text { giderme alanı olarak } \\
\text { sinıf yönetimi. }\end{array}$ & $\begin{array}{l}6 \\
\% 5,71\end{array}$ & $\begin{array}{l}\text { Arena } 1 \text {, hayat } 1 \text {, sanat } 1 \text {, suya } \\
\text { vurulan darbe } 1 \text {, suya urgan } \\
\text { bağlamak } 1 \text {, yolculuk } 1 \text {. }\end{array}$ & $\begin{array}{l}6 \\
\% 10,52\end{array}$ \\
\hline $\begin{array}{l}\text { 6. Hassas / Risk alınan } \\
\text { bir süreç olarak sınıf } \\
\text { yönetimi. }\end{array}$ & $\begin{array}{l}5 \\
\% 4,76\end{array}$ & $\begin{array}{l}\text { Araç motoru } 1 \text {, giriş̧imcilik } 1 \text {, } \\
\text { kelebek } 1 \text {, kuş } 1 \text {, yumurta } 1 \text {. }\end{array}$ & $\begin{array}{l}5 \\
\% 8,77\end{array}$ \\
\hline
\end{tabular}

Kategori 1. Ahenk / Uyum içerisinde yürütülen bir sanat olarak sınıf yönetimi. Tablo 9 incelendiğinde bu kategori 34 öğretmen $(\% 32,38)$ ve 11 metafor $(\% 19,29)$ ile temsil edilmektedir. Bu kategorideki metaforlar; araba kullanmak, beste, dantel örmek, galaksi, labut çevirmek, müzik aleti çalmak, orkestra yönetmek, renk spektrumu, sahne yönetmek, seyislik, yönetmenlik olarak belirlenmiştir. Aşağıda bu kategoriye ait metafor örnekleri verilmiştir.

\section{Araba kullanmak:}

Sınıf yönetimi araba kullanmak gibidir. Çünkü aynı anda pek çok unsuru kontrol etmeniz gerekir (Ö94, kadın, 1-3).

\section{Beste:}

Sinlf yönetimi bir beste gibidir. Çünkü tıpk bestelerde olduğu gibi onun da notaları ve belli bir ahengi vardır. Notaları doğru sirada ve dikkatle kullanırsanız sonucunda ögrenciler için faydalı bir eğitimci olabilirsiniz (Ö13, erkek, 21-27). 


\section{Dantel örmek:}

Sinıf yönetimi dantel örmek gibidir. Çünkü her bir ilmeği uyum ile işlemek ve sabır gerektirir. Fakat sabrın sonunda ortaya harika bir sanat örneği çıkar (Ö23, kadın, 1 $3)$.

\section{Labut çevirmek:}

Sınıf yönetimi labut çevirmek gibidir. Çünkü tüm sınıfı bir arada tutabilmeli, birisine odaklanınca diğerlerini gözden kaçırmamalısınız (Ö53, erkek,21-27).

\section{Orkestra yönetmek:}

Sinıf yönetimi orkestra yönetmek gibidir. Çünkü farklı müzik aletlerinden uyumlu ahenkli eserler ortaya çıkar (Ö55, kadın, 21-27).

Sinıf yönetimi orkestra yönetimi gibidir. Çünkü ayrı sesleri, bir ahenk içerisinde ve dengede tutar (Ö42, erkek, 21-27).

Sinıf yönetimi orkestra yönetmeye benzer. Çünkü öğretmenler tıpkı farklı enstrümanlarla çalışan orkestra şefi gibi farklı özelliklere sahip ögrencilerle çalışır. Bütün bu farkllliklar orkestra şefinin yönetimiyle güzel bir eser meydana getirir. Öğretmenler de farkl bireysel özelliklere sahip ögrencilerle sinıf yönetimini iyi kullanarak verimli bir ögrenme ortamı oluştururlar (Ö45, kadın, 9-14).

\section{Yönetmenlik:}

Sinıf yönetimi yönetmenlik gibidir. Çünkü oyunu iyi yönetmek ve oyuncularla uyumlu çalışmak başarıyı getirecektir. (Ö92, kadın, 9-14).

Kategori 2. Yol gösteren / Şekil veren bir süreç olarak sınıf yönetimi. Tablo 9'a göre bu kategori 23 öğretmen $(\% 21,90)$ ve 13 metafor $(\%$ 22,80) ile temsil edilmektedir. Bu kategorideki metaforlar; arının bal toplaması, antrenman sahası, bahçıvanlık, çiçek bakımı, çiftçilik, çobanlık, dülgerlik, ekin ekmek, geleceğe yatırım yapmak, gemi kaptanlı̆̆l, güneş, marangozluk, saat olarak belirlenmiştir. Aşağıda bu kategoriye ait metafor örnekleri verilmiştir.

\section{Arının bal yapması:}

Sınıf yönetimi arıların bal yapması gibidir. Çünkü verimli çiçeklerden toplanan balın kalitesi çok daha fazla olacaktır (Ö15, kadın, 28 ve üstü).

\section{Bahçıvanlık:}

Sınıf yönetimi bahçıvanlık gibidir. Çünkü tohumları, açmaya hazır tomurcukları yetiştirirsin. Tüm sevgini, enerjini onlara verirsin. (Ö50, kadın, 15-20).

\section{Çiçek bakımı:}

Sınıf yönetimi çiçek bakımı gibidir, çünkü her öğrencinin ihtiyacı farklıdır. Onu yetiştirirken farklı yöntemler kullanırız (Ö51, kadın, 15-20).

\section{Çiftçilik:}

Sınıf yönetimi çiftçilik gibidir. Çünkü çiftçi toprağını ve mahsulünü iyi yetiştirmek için ne kadar ilgilenirse o kadar çok verim elde eder (Ö68, erkek, 4-8).

\section{Çobanlık:}

Sinıf yönetimi çobanlı̆̆a benzer. Çünkü sınıfin çobanı ögretmenlerdir. Sürü yani yönetilenler ise çocuklar, çoban onları besleyecek otlar ne tarafta bilir. Ĕger onları besleyecek tarafa ilerlerse büyür ve gelişirler. Fakat bu rastgele olursa sürü dăgl lır ve birbirinden kopar (Ö11, kadın, 1-3). 


\section{Gemi kaptanlığı:}

Sinıf yönetimi gemi kaptanlı̆̆ına benzer. Çünkü geminin her türlü şartta să̆ salim karaya ulaştırılması gibi ögretmenler de ögrencilere doğru yolu gösterirler (Ö104, kadin, 15-20).

\section{Güneş:}

Sınıf yönetimi güneş gibidir. Çünkü her eğitimci ögrencilerini sevgisiyle ısıtır, bilgisiyle aydinlatır (Ö82, erkek, 9-14).

\section{Marangozluk:}

Sinıf yönetimi ăgaç işlenen bir marangoz gibidir. Çünkü ögrenciler şekil verilmeyi ve yoğrulmayı bekleyen hammadde gibidir. Ona ne işlersen, karşılığını göreceğin bir kaynaktır (Ö16, kadın, 1-3).

Kategori 3. Yönetim / Otorite alanı olarak sınıf yönetimi. Tablo 9'a göre bu kategori 20 öğretmen (\% 19,04) ve 7 metafor (\% 12,28) ile temsil edilmektedir. Bu kategorideki metaforlar; aile yönetmek, devlet yönetmek, ev geçindirmek, fabrika yönetmek, ocak yönetmek, ülke, ülke emniyeti olarak belirlenmiştir. Aşağıda bu kategoride yer alan metaforlara ilişkin örneklere yer verilmiştir.

\section{Aile yönetmek:}

Sınıf yönetimi aile yönetmek gibidir. Çünkü bir aileyi săg-salim yönetmek ve herkesi mutlu etmek gerekir (Ö19, kadın, 4-8).

\section{Devlet yönetmek:}

Sinıf yönetimi toplumu yöneten devlete benzer. Çünkü kuralları ve yöneticisi vardır (Ö46, erkek, 9-14).

Sinıf yönetimi devlet yönetimi gibidir. Çünkü irfanla muktedir olunmazsa devrilir (Ö69, erkek, 15,20).

\section{Fabrika yönetmek:}

Bir fabrika yönetmek gibidir. Çünkü sınıfta çalışan ürün ve yönetici var. Çalışan çocuklar, ürün bilgi, yönetici de ögretmendir. Doğru bir yönetim olursa, bilgiyi dilediğimiz gibi işleyip kullanabilirler (Ö8, kadın, 4-8).

\section{Ocak yönetimi:}

Sinıf yönetimi ocak yönetimine benzer. Çünkü ocağın tütmesini sağlayamayan kimse nasıl ocă̆ını söndürürse, ocă̆ını her türlü tehdide răgmen canlı tutan kimse gibi sinıfinı aktif ve canlı tutan orayı kurallar ile bir öğretim mekânı yapan öğretmen de ocă̆ını tüttüren ögrencisi olduğu müddetçe bedeni ölse de yaşamaya devam edecektir (Ö38, erkek, 21-27).

\section{Ülke:}

Sinıf yönetimi ülkeye benzer. Çünkü içinde her renkten ve ırktan insanların olduğu bu ülkeyi herkesin taleplerini göz önünde bulundurarak ve adaleti sağlayarak yönetmek gerekir (Ö12, kadın, 4-8).

Kategori 4. Düzen / Kontrol alanı olarak sınıf yönetimi. Tablo 9 incelendiğinde bu kategori 17 öğretmen $(\%$ 16,19) ve 15 metafor (\% 26,31) ile temsil edilmektedir. Bu kategorideki metaforlar; ahtapot, arı kovanı, ayar düğmesi, baraj, bekçi, deney yapmak, doğa kanunları, futbol takımı yönetmek, makine, masa ayağı, meddahlık, seçim pusulası, sinir sistemi, terazi, toprak işlemek olarak belirlenmiştir. Aşağıda bu kategoriye ait metafor örnekleri verilmiştir. 


\begin{abstract}
Ahtapot:
Sinıf yönetimi ahtapot gibidir. Çünkü ögretmenin sinıfta yaşanan olaylara eş zamanlı olarak yetişmesi gerekir. Çocuk öğretmenin gözetimi altında olduğunun her yerde farkında olmalı ama ögretmen bunu fark ettirmeden yapmal, yeri geldiğinde bunu ona hissettirmelidir (Ö6, kadın, 1-3).
\end{abstract}

\title{
Arı kovanı:
}

Sınıf yönetimi arı kovanı gibidir. Çünkü her şeyin düzenli olması lazım (Ö93, erkek, 48).

\section{Ayar düğmesi:}

Sınıf yönetimi ayar düğmesi gibidir. Çünkü sınıfin düzeni duruma göre ayarlanır (Ö62, kadin, 9-14).

\section{Bekçi:}

Sınıf yönetimi bekçilik gibidir. Kimsenin sıkıntı yaşamaması ve sınıfin düzeni için mücadele etmektir (Ö102, kadın, 21-27).

\section{Doğa kanunu:}

Sınıf yönetimi doğa kanunları gibidir. Çünkü dünyadaki düzeni sağlayan kanunlar gibi sinıf yönetimi de sınıfta düzeni sağlar (Ö103, erkek, 21-27).

\section{Makine:}

Sınıf yönetimi makineye benzer. Çünkü işlerin yolunda gitmesi için bir düzene ve kontrole ihtiyaç vardır (Ö57, erkek, 4-8).

\section{Terazi:}

Sınıf yönetimi dengede tutmamız gereken terazi gibidir. Çünkü sınıfta düzeni sağlamak için hem sevgiyi hem de sayglyı dengede tutmak gerekir (Ö44, kadın 1-3).

Kategori 5. Mücadele / Sorun giderme alanı olarak sınıf yönetimi. Tablo 9'a göre bu kategori 6 ögretmen $(\% 5,71)$ ve 6 metafor $(\%$ 10,52) ile temsil edilmektedir. Bu kategorideki metaforlar; arena, hayat, sanat, suya vurulan darbe, suya urgan bağlamak, yolculuk olarak belirlenmiştir. Aşağıda bu kategoriye ait metafor örnekleri verilmiştir.

\section{Arena:}

Sinlf yönetimi arena gibidir. Çünkü iyi bir yönetim olmazsa istenmeyen sorunlar ortaya çıkar (Ö90, erkek, 15-20).

\section{Sanat:}

Sınıf yönetimi sanat gibidir. Çünkü sinıfı hakklyla yönetmek tıpkı bir sanatı icra eden sanatçı gibi bilgi, beceri ve yetenekle birlikte ciddi bir mücadele gerektirir (Ö̈48, erkek, 9-14).

\section{Suya urgan bağlamak:}

Sinıf yönetimi suya urgan bağlamaya benzer. Çünkü neredeyse hiçbir öğrenci sizin kurallarınızı gerçek hayatla ilişkilendiremez (Ö101, erkek, 9-14).

Kategori 6. Hassas / Risk alınan bir süreç olarak sınıf yönetimi. Tablo 9'a göre bu kategori 5 öğretmen $(\% 4,76)$ ve 5 metafor $(\% 8,77)$ ile temsil edilmektedir. Bu kategorideki metaforlar; araç motoru, girişimcilik, kelebek, kuş, yumurta olarak belirlenmiştir. Aşağıda bu kategoriye ait metafor örnekleri verilmiştir. 


\section{Araç motoru:}

Sınıf yönetimi araç motoru gibidir. Çünkü bir yerinde problem olursa diğer aksamlara da zarar verir (Ö81, erkek, 4-8).

\section{Kelebek:}

Kelebek gibidir. Fazla sıkarsan boğarsın, serbest bırakırsan elinden uçup gider (Ö5, erkek, 4-8).

\section{Yumurta:}

Sınıf yönetimi yumurta gibidir. Çünkü çok sert davranırsan kırılır, çok gevşek davranırsan da elinde tutamazsin yine kırllır. (Ö9, kadın, 1-3).

\section{TARTIŞMA, SONUÇ VE ÖNERÍLER}

Din öğretimi alan dersleri öğretmenlerinin sınıf ve sınıf yönetimi algılarını tespit etmeyi ve değerlendirmeyi amaçlayan bu araştırma bulgularına göre; öğretmenler sınıfı 44 farklı metafor, sınıf yönetimini 57 farklı metafor üzerinden açıklamıştır. Bu durum öğretmenler tarafından sınıf ve sınıf yönetimi kavramlarını geniş bir metaforik algıya sahip olduklarını göstermektedir.

Öğretmenler hem sınıfi hem de sınıf yönetimini tanımlarken ortak metaforlar kullanmışlardır. Öğretmenler sınıf kavramını tanımlamak için aile, arı kovanı, devlet, doğa, futbol, ocak, orkestra, sahne, toprak gibi metaforlar kullanılırken sınıf yönetimini tanımlamak için benzer olarak aile yönetmek, arı kovanı, devlet yönetmek, doğa kanunları, ocak yönetmek, orkestra yönetmek, sahne yönetmek, toprak işlemek gibi metaforlar kullanmışlardır.

Sınıf kavramını tanımlarken en çok kullanılan metaforlar (1) bahçe, 23 öğretmen, \%21,90; (2) sahne, 9, \%8,57; (3) aile, 7, \%6,66; (4) ev, 7, \%6,66 (5) ar1 kovan1 4, \% 3,80; (6) ayna 4, \% 3,80; (7) toprak 4, \% 3,80 olarak belirkenmiştir. Uzun ve Paliç'in (2013) sınıf öğretmenlerinin sınıf kavramına yönelik sahip oldukları algıları metaforlar aracılı̆̆ıyla incelediği araștırmada 28 farklı metafor üretilmiştir. En çok kullanılan metaforlar aile ortamı (12), bahçe (11), ev/yuva (11), dünya (5) ve öğrenme ortamı (4) olarak belirlenmiştir. İki araştırma karşılaştırıldığında ilk beş metafor arasındaki bahçe ve aile metaforları ortaktır. Benzer olarak ifade edilebilecek Nalçacı ve Bektaş'ın (2012) öğretmen adaylarının okul kavramına ilişkin algılarını metaforlar yardımıyla inceleyen araştırmada 83 metafor belirlenmiş̧iir. Bu araştırmada ilk beş sırada; aile/ev/yuva (187), hayat (95), hapishane (319), fabrika (29), toplum (18) metaforları yer almaktadır. İki araştırma karşılaştırıldığında ilk beş metafor arasındaki aile metaforu ortaktır. Tekrar benzer olarak ifade edilebilecek alanyazında öğretmen üzerine yapılan metaforik araştırmalardan söz edilebilir. Yılmaz ve diğerlerinin (2013) öğretmen adaylarının öğretmen kavramına yönelik algılarını metaforlar üzerinden belirlediği araştırmada 141 metafor belirlenmiştir. İlk beş sırada "anne-baba (34), bahçıvan (23), anne (21), rehber (21), aile (14)" metaforları sıralanmaktadır. İki araştırma karşılaştırıldığında ilk beş metafor arasındaki anne-baba, anne, aile metaforları arasında benzerlik vardır. Buna göre bu araştırma ile Uzun ve Paliç (2013), Nalçacı ve Bektaş (2012) ve Yılmaz ve diğerlerinin (2013) bulguları örtüşmektedir.

Din öğretimi alan öğretmenlerinin sınıfi tanımlarken ürettikleri metaforlar 8 kavramsal kategoride toplanmıştır. Bu kategoriler, bireysel gelişim kaynağı, sevgi ve güven kaynăğ, şekillendiren / geleceğe yön veren ortam, zengin bir yaşam alanı, dikkatli ve yoğun bir çalışma alanı, aydınlatan ortam, bilgi kaynağı, keşif kaynağı olarak sınıftır. Uzun ve Paliç'in (2013) araştırmasında sınıf öğretmenlerinin sınıf tanımlamaları 8 kavramsal kategoride toplanmıştır. $\mathrm{Bu}$ kategoriler, sıcak/samimi ortam, farklılıkları barındıran ortam, bilgi ve beceri kazanılan 
ortam, zevkli ve eğlenceli ortam, şekillendirici/tedavi edici ortam, takım çalışması (işbirliği) gerektiren ortam, boş zihinleri barındıran ortam, hedefe ulaştıran ortam olarak sınıftır. Buna göre iki araştırmada elde edilen bulgular örtüşmektedir. Şöyle ki; bu araştırmada sevgi ve güven kaynağı, şekillendiren / geleceğe yön veren ortam, zengin bir yaşam alanı, dikkatli ve yoğun bir çalışma alanı olarak sınıf kategorileri ile Uzun ve Paliç'in (2013) araştırmasındaki sıcak/samimi ortam, farklılıkları barındıran ortam, bilgi ve beceri kazanılan ortam, şekillendirici/tedavi edici ortam olarak sınıf kategorileri arasında benzerlik vardır. Nalçacı ve Bektaş'ın (2012) araştırmasında okul kavramına yönelik metaforlar 11 kavramsal kategoride toplanmıştır. Bunlar, vazgeçilmez, olumsuz, yönlendirici, sosyal ortam, yarış, eğlendirici, biçimlendirici, gelişme, otorite, güven verici, bilgi sağlayıcı olarak okuldur. İki araştırma bulguları arasında benzerlik vardır. Şöyle ki, bu araştırmada sevgi ve güven kaynağı, şekillendiren / geleceğe yön veren ortam, dikkatli ve yoğun bir çalışma alanı olarak sınıf kategorileri ile Nalçacı ve Bektaş'ın (2012) yönlendirici, biçimlendirici, güven verici, bilgi sağlayıcı kategorileri arasında benzerlik vardır. Yılmaz ve diğerlerinin (2013) araştırmasında öğretmen kavramına yönelik metaforlar 7 kavramsal kategoride toplanmıştır. Bunlar, şekillendirici, yol gösterici, bilgi kaynağı olan, statüsü olmayan, esnek, model olan, kutsal bir iş yapan öğretmen kategorileridir. İki araştırma arasında da benzerlik vardır. Buna göre bu araştırmanın bulguları ile Yılmaz ve diğerlerinin (2013) şekillendirici, yol gösterici, bilgi kaynağı olan öğretmen kategorileri arasında benzerlik vardır. Buna göre bu araştırma ile Uzun ve Paliç (2013), Nalçacı ve Bektaş (2012) ile Yılmaz ve diğerlerinin (2013) bulguları örtüşmektedir.

Öğretmenlerin sınıf yönetimini tanımlarken en çok kullandıkları metaforlar, (1) orkestra yönetmek 18 öğretmen, \%17,14. (2) aile yönetmek 8, \% 7,61. (3) devlet yönetmek 6, \%5,71. (4) araba kullanmak, 4, \% 3,80. (5) çiçek bakımı, 4, \% 3,80 olarak belirlenmiştir. Turhan ve Yaraş'ın (2013) öğretmen ve öğrencilerin öğretmen, disiplin, müdür, sınıf kuralları, ödül ve ceza kavramlarına ilişkin metaforik algılarını belirleyen araştırmasında disiplin kavramına yönelik 19 metafor üretilmiştir. İki araştırma karşılaştırıldığında sınıf yönetimi tanımlanırken kullanılan oyun hamuru ve pusula metaforlarının ortak olduğu görülmektedir. Aynı araştırmada sınıf kuralları tanımlanırken 19 metafor belirlenmiştir. Bunlar arasında yer alan ayak, saç ayağı, terazi, saat gibi metaforlar bu araştırmada sınıf yönetimi tanımlanırken kullanılan metaforlarla ortaktır. Aynı şekilde Ekici ve Akdeniz'in (2018) öğretmen adaylarının sınıfta disiplin sağlamak kavramına ilişkin algılarının metaforlar aracıllı̆ıyla belirlendiği araştırmada 38 metafor tespit edilmiştir. İlk beş sıradaki metaforlar deveye hendek atlatmak, sürüyü gütmek, çobanlık, devlet yönetmek, askerlik olarak belirlenmiştir. İki araştırma bulguları arasında benzerlik vardır. Şöyle ki, bu araştırmada belirlenen ilk beş metafordan birisi olan devlet yönetmek ile Ekici ve Akdeniz'in (2018) araştırmasındaki devlet yönetmek metaforu ortaktır. Ayrıca Ekici ve Akdeniz'in (2018) araştırmasında sınıfta disiplini sağlamak kavramı tanımlanırken kullanılan çobanlık, gösteri yapmak, sürüyü gütmek gibi metaforlar bu araştırmada kullanılan metaforlar ile ortaktır. Buna göre bu araştırma ile Turhan ve Yaraş (2013) ile Ekici ve Akdeniz'in (2018) bulguları örtüşmektedir.

Din öğretimi alan öğretmenlerinin sınıf yönetimini tanımlarken ürettikleri metaforlar 6 kavramsal kategoride toplanmıştır. Bu kategoriler, ahenk / uyum içerisinde yürütülen bir sanat, yol gösteren / yetiştiren bir süreç, yönetim / otorite alan1, düzen / kontrol alanı, mücadele / sorun giderme alanı, hassas / risk alınan bir süreç olarak sınıf yönetimidir. Turhan ve Yaraş’ın (2013) araştırmasında disiplin tanımlanırken kullanılan metaforlar 3 kavramsal kategoride toplanmıştır. Bunlar olumsuz bir unsur, düzeltici ve yol gösterici, zorunlu bir unsur olarak disiplindir. Ayn1 araştırmada sınıf kuralları tanımlanırken kullanılan metaforlar 3 kavramsal kategoride toplanmıştır. Bunlar, dengeyi sağlayıcı, düzenleyici - düzeltici, koruyucu ve gerekli olarak sınıf kurallarıdır. İki araştırma bulguları arasında benzerlik vardır. Şöyle ki, bu araştırmada yol gösteren / yetiştiren bir süreç olarak sınıf yönetimi kategorisi ile Turhan ve Yaraş'ın (2013) düzeltici ve yol gösterici olarak disiplin ile düzenleyici - düzeltici olarak sinıf kuralları kategorileri arasında benzerlik vardır. Ekici ve Akdeniz'in (2018) araştırmasında sınıfta disiplin 
sağlamak tanımlanırken kullanılan metaforlar 4 kavramsal kategoride toplanmıştır. Bunlar, kontrol altında tutmak, özel çaba harcamak, zoraki bir şeyler yaptırmak ve güç gösterisi yapmaktır. İki araştırma bulguları arasında benzerlik vardır. Şöyle ki, bu araştırmada belirlenen düzen / kontrol alanı, mücadele / sorun giderme alanı, hassas / risk alınan bir süreç olarak sınıf yönetimi kategorileri ile Ekici ve Akdeniz'in (2018) kontrol altında tutmak ve özel çaba harcamak kategorileri arasında benzerlik vardır. Buna göre bu araştırma ile Turhan ve Yaraş (2013) ile Ekici ve Akdeniz'in (2018) bulguları örtüşmektedir.

Metaforlar insanların iletişim kurarken kullandıkları önemli araçlardan biridir. İnsanlar metaforu iki şey arasındaki benzerlikten hareketle soyut kavramları somutlaştırmak, karmaşık olan kavramları sadeleştirmek, bilinmeyen kavramları açıklamak amacıyla kullanırlar. Ayrıca metaforlar bireysel algilarn belirlenmesinde ve zihinsel imgelerin kategorize edilmesinde de kullanılır. Çok farklı alanlarda kullanılan metaforların kullanım alanlarından bir tanesi de eğitim-öğretimdir. Hem din öğretimi alan öğretmenlerinin eğitiminde hem de öğretmenlerin din öğretimi faaliyetlerinde metaforlar önemle kullanılmalıdır. Zira din eğitimi ve öğretimi alanında özellikle soyut kavramların somutlaştırılmasında metaforlar anlamayı kolaylaştırmada önemli bir araç olacaktır.

Eğitim sisteminin ilk ve temel basamağı olarak sınıf, okullarda eğitim öğretim faaliyetlerinin gerçekleştiği bir yaşama alanıdır. Sınıf içindeki yaşantıların, belirlenmiş kazanımlara uygun olarak gerçekleşmesi öğretim lideri olarak öğretmenin sorumluluğudur ve iyi bir sınıf yönetimi bilgisi ve becerisi gerektirir. Tüm öğretmen yetiştiren kurumlarda nitelikli formasyon bilgi ve becerisi, özelikle sınıf yönetimi becerisi bir gereksinimdir. Din eğitimi ve öğretimi temelde iman, ibadet ve ahlak alanlarını kapsayan bir bilgi aktarımı ile birlikte yetişen bireylerin din ve dindarlık algılarına da yön veren önemi tartışılmaz bir alandır. Bu alanın temsilcisi olan din öğretimi alan öğretmenleri de yeterli ve kaliteli olmak zorundadırlar. Bu sorumluluğu yerine getirilebilmek için din öğretimi alan öğretmenleri hem etkili ve verimli bir öğrenme ortamı oluşturmaya çalışacak hem de sınıfı iyi bir öğretim lideri olarak yönetecektir. $\mathrm{Bu}$ amaçla öğretmenlerin, sınıf kurallarını belirlemesi, uygun bir sınıf düzenini sağlaması, öğretimi ve zamanı etkili bir şekilde yönetmesi, öğrenci davranışlarını denetleyerek sınıfta olumlu bir öğrenme iklimi oluşturması gerekmektedir. $\mathrm{Bu}$ da öğretmenlerin çağdaş sınıf yönetimi yaklaşım ve modellerine sahip olması ile mümkün olacaktır.

$\mathrm{Bu}$ araştırmanın amacı din öğretimi alan öğretmenlerinin sınıf ve sınıf yönetimi algılarını metaforlar aracılığ ile belirlemek ve bu metafor imgelerini bazı kavramsal kategoriler altında toplamaktır. Bu amaçla 105 öğretmen yarı yapılandırılmış form aracılığıyla sınıf ve sınıf yönetimi ile ilgili metaforlar geliştirmişlerdir.

105 öğretmen sınıf kavramı ile ilgili olarak 44 metafor geliştirmiştir. Buna göre öğretmenler sınıfı çok geniş bir metaforik algı ile algılamaktadırlar. Sınıfı algılarken öğretmenler bahçe, sahne, ev, aile vb. olumlu metaforlar kullanmışlardır. Buna göre ögretmenlerin sınıf ile ilgili pozitif algılarının negatif algılarından çok daha baskın olduğu belirlenmiştir. Sınıf tanımlanırken en çok kullanılan bahçe metaforu, sınıfın öğrencilerin bireysel gelişimlerine yön veren bir ortam olarak algılandığını göstermektedir. Buna göre öğretmenler öğrencilerin bireysel gelişimlerine yön verme ve bu amaçla onlara liderlik yapma sorumluluklarının farkındadırlar. Aynı şekilde sınıf tanımlanırken kullanılan aile ve ev gibi metaforlar öğretmenlerin sınıfı sıcak / samimi bir ortam olarak algıladıklarını göstermektedir. Buna göre öğretmenler öğrencileri kendi ailelerinden bireyler olarak görmekte, onları çocukları gibi algılamaktadırlar. Sahne metaforu da çok kullanılan metaforlar arasındadır. Öğretmenler bu metafor ile sınıfı öğrencilerin yaratıcılıklarını geliştiren bir ortam olarak algılamaktadırlar. Arı kovanı metaforu ile öğretmenler sınıfı dikkat ve özenle çalışılması gereken bir ortam olarak algılamaktadırlar. Ayna metaforu ile öğretmenlerin sınıfı öğrencileri aydınlatan bir ortam olarak düşünmektedirler. Ayrıca bu metafor ile öğrencilerin kazandıkları tutum ve davranışlarla öğretmenlerini yansıtacaklarını ve öğretmenlerin öğrencileri buna göre yetiştirmek gerektiği 
bilincinde oldukları da düşünülebilir. Toprak metaforu ile öğretmenler sınıfı öğrencilerin bireysel gelişim ortamı olarak algılamaktadırlar. Öğretmenlerin sınıfı tanımlarken ürettikleri metaforlar 8 kavramsal kategoride toplanmıştır. Bu kategoriler, bireysel gelişim kaynağı, sevgi ve güven kaynağı, şekillendiren / geleceğe yön veren ortam, zengin bir yaşam alanı, dikkatli ve yoğun bir çalışma alanı, aydınlatan ortam, bilgi kaynağı, keşif kaynağı olarak sınıftır. Öğretmenlerin sınıf içi tutum ve davranışlarında karakter özellikleri, öğretmenlik bilgi ve becerileri, sınıf algıları önemli olduğuna göre din öğretimi alan öğretmenlerinin yukarıda ifade edilen sınıfı bireysel gelişim kaynağı, sevgi ve güven kaynağı, şekillendiren / geleceğe yön veren ortam vb. gibi gören pozitif sınıf algıları onların ve öğrencilerinin başarısına katkı sağlayacaktır.

105 öğretmen sınıf yönetimi kavramı ile ilgili olarak 57 metafor geliştirmiştir. Buna göre öğretmenler sınıf yönetimini çok geniş bir metaforik algı ile algılamaktadırlar. Öğretmenler sınıf yönetimini orkestra yönetmek, aile yönetmek, devlet yönetmek, araba kullanmak, çiçek bakımı vb. olumlu metaforlar kullanmışlardır. Buna göre öğretmenlerin sınıf yönetimiyle ilgili pozitif algılarının negatif algılarından çok daha baskın olduğu belirlenmiştir. Sınıf yönetimi tanımlanırken en çok kullanılan orkestra yönetmek metaforu öğretmenlerin sınıf yönetimini farklı enstrümanların ahenkli bir şekilde yönetilmesi olarak algıladıklarını göstermektedir. Buna göre öğretmenler sınıf yönetimini ilgileri, yetenekleri ve zekâ düzeyleri birbirlerinden farklı olan öğrencileri ahenk / uyum içerisinde yönetme olarak algılamaktadırlar. Ayrıca bu tanımlama öğretmenlerin zengin sınıf ortamında öğrencilerin bireysel farklılıklarına uygun çağdaş sınıf yönetimi yaklaşımlarının kullanılması gerekliliğinin farkındalığı olarak düşünülmelidir. Aile yönetmek metaforu ile sınıf yönetimi bir ebeveyn gibi sınıf ortamında öğrencilere şefkat ve merhametle davranılması gerekliliği olarak algılanmaktadır. Bu da yukarıda bahsi geçen sınıfı tanımlarken kullanılan aile metaforu ile uyumludur. Devlet yönetmek metaforu öğretmenlerin sınıf yönetimini bir otorite unsuru olarak da gördüklerini göstermektedir. Buna göre öğretmenler sınıf ortamında gerekli kuralların koyulması, düzenin sağlanması ve öğrencinin kural koyma sürecine aktif olarak katılımını da önemsemektedirler. Özellikle öğretmenlerin kuralların öğrenciler ile birlikte belirlenmesi gerekliliğine dair yaklaşımlarının çağdaş sınıf yönetimi anlayışı açısından önemi büyüktür. Araba kullanmak metaforu da çok kullanılan metaforlar arasındadır. Bu metafor ile öğretmenler sınıf yönetimini ahenk / uyum içerisinde yürütülmesi gereken bir iş olarak algılamaktadırlar. Çiçek bakımı metaforu ile öğretmenler sınıf yönetimini yol gösteren / yetiştiren bir süreç olarak algılamaktadırlar. Buna göre öğretmenler öğrencilerine yol gösterme, onları yetiştirme sürecine aracılık edebilecek çağdaş bir sinıf yönetimi anlayışını önemsediklerini belirtmektedirler. Öğretmenlerinin sınıf yönetimini tanımlarken ürettikleri metaforlar 6 kavramsal kategoride toplanmıştır. Bu kategoriler, ahenk / uyum içerisinde yürütülen bir sanat, yol gösteren / yetiştiren bir süreç, yönetim / otorite alanı, düzen / kontrol alanı, mücadele / sorun giderme alanı, hassas / risk alınan bir süreç olarak sınıf yönetimidir. Buna göre öğretmenlerin sınıf yönetimine dair pozitif algıları, sınıf ortamının özellikleri içerisinde yer alan çok boyutluluk, eş zamanlılık gibi sınıfta aynı anda pek çok unsuru yönetme üzerine sahip oldukları pozitif anlayışlar öğretmenlerin sınıf yönetimindeki başarılarına olumlu katkı sağlayacaktır.

Araştırma sonuçlarına göre şu öneriler geliştirilmiştir:

- Din öğretimi alan öğretmenlerine metafor, metafor oluşturma, metaforun önemi gibi konularda bilgiler verilmelidir.

- Din öğretimi alan öğretmenleri din öğretimi alan derslerinin soyut konu / kavramlarının öğretiminde metaforlar kullanmalıdırlar.

- Din öğretimi alan öğretmenlerinin sınıf ve sınıf yönetimi algılarını ortaya koyan farklı yöntemler kullanan araştırmalar yapılabilir. Elde edilen bulgular bu araştırma bulguları ile karşılaştırılabilir. 
- Din öğretimi alan öğretmenleri ve diğer alanlardan öğretmenler ile sinıf ve sinıf yönetimi ile ilgili algılarını tespit edebilmek amacıyla benzer araştırmalar yapılabilir. $\mathrm{Bu}$ araştırmalarda elde edilen bulgular ile yeni araştırma bulguları arasında karşılaştırmalar yapılabilir.

- Benzer bir araştırma din öğretimi aday öğretmenleri ile yapılabilir. Aday öğretmenler ile öğretmenlerin sınıf ve sınıf yönetimi algıları arasında karşılaştırmalar yapılabilir.

- Din öğretimi aday öğretmenleri ile eğitim fakültelerinde öğrenim gören aday ögretmenler arasında benzer araştırmalar yapılabilir. Onların sınıf ve sınıf yönetimi algıları karşılaştırılabilir.

\section{KAYNAKÇA}

Acuner, H.Y. ve Erbaş, A. A. (2016). Din kültürü ve ahlak bilgisi ve diğer branş öğretmenlerine göre din kültürü ve ahlak bilgisi öğretmenlerinin yeterlikleri. Dinbilimleri Akademik Araştırma Dergisi, 16(1), 147-170.

Akın, U. ve Koçak, R. (2007). Öğretmenlerin sınıf yönetimi becerileri ile iş doyumları arasındaki ilişki. Kuram ve Uygulamada Eğitim Yönetimi, 51, 353-370.

Altıntaş, M. E. (2017). İlköğretim Din Kültürü ve Ahlak Bilgisi dersi öğretmenlerinin değer öğretiminde benimsedikleri sınıf yönetimi yaklaşımı-nitel bir araştırma. Bilimname, 34(2), 465-498.

Arslan, M. M. ve Bayrakçı, M. (2006). Metaforik düşünme ve öğrenme yaklaşımının etkili öğretim açısından incelenmesi. Milli Ĕgitim Dergisi, 171, 100-108.

Aydın, M. Ş. (2005). Cumhuriyet döneminde din eğitimi öğretmeni yetiştirme ve istihdamı. İstanbul: Değerler Eğitimi Merkezi Yayınları.

Aydın, A. (2005). Sinıf yönetimi (6. Baskı). Ankara: Anı Yayıncılık.

Aydın, A. (2009). Sinıf yönetimi. Ankara: Pegem Akademi Yayıncılık.

Aydın, F. (2010). Ortaöğretim öğrencilerinin coğrafya kavramına ilişkin sahip oldukları metaforlar. Kuram ve Uygulamada Eğitim Bilimleri, 10(3), 1293-1322.

Baker P.J. (1991). Metaphors of mindful engagement and a vision of beter schools. Educational Leadership, 48(6), 32-35.

Balay, R. (2003). 2000' li yıllarda sinıf yönetimi (2. Bask1). Ankara: Sandal Yayınları.

Balc1, A. (1999). Metaphorical images of school: School perceptions of students, teachers and parents from four selected schools (in Ankara). (Yayınlanmamış Doktora Tezi). Orta Doğu Teknik Üniversitesi, Ankara. Erişim adresi: file:///C:/Users/HP/Downloads/082164\%20(1).pdf

Baltac1, A. (2017). Nitel veri analizinde Miles-Huberman modeli. Ahi Evran Üniversitesi Sosyal Bilimler Enstitüsü Dergisi (AEÜSBED), 3(11), 1-15.

Baltacı, A. (2019). Din dersi öğretmenlerinin sınıf yönetimi yaklaşımları: etnometodolojik bir araştırma. Dinbilimleri Akademik Araştırma Dergisi, 19(2), 293-321. DOİ: 10.33415/daad.567729.

Baş, T. ve Akturan, U. (2008). Nitel araştırma yöntemleri. Ankara: Seçkin Yayıncılık.

Başar, H. (2009). Sinıf yönetimi (15. Baskı). Ankara: Anı Yayıncılık. 
Başar, E. (2013). Türkiye'deki eğitimin tarihsel gelişimi. İçinde: Özcan Demirel, Zeki Kaya (Ed.) Eğitim bilimine giriş (8. Baskı) (ss.23-66). Ankara: Pegem Akademi Yayıncılık.

Beytekin, O. F. (2016). Sınıf yönetiminin temelleri. İçinde: İkram Çınar (Ed.) Sinıf yönetimi. (ss.1-20). Ankara: Eğiten Kitap Yayınları.

Bilgin, B. (1983). Din dersi öğretmenliği ve güçlükleri. Ankara Üniversitesi İlahiyat Fakültesi Dergisi, 26(1), 259-263.

Cerit, Y. (2008). Öğretmen kavramı ile ilgili metaforlara ilişkin öğrenci, öğretmen ve yöneticilerin görüşleri. Türk Eğitim Bilimleri Dergisi, 6(4), 693-712.

Çakmak, F. (2021). Öğretmen adayları ve öğretmenlerin öğretmenlik ile ilgili metaforik algılarının incelenmesi. Bayburt Eğitim Fakültesi Dergisi, 16(31), 219-251. https://doi.org/10.35675/befdergi.726660.

Çalık, T. (2012). Sınıf yönetimi ile ilgili temel kavramlar. İçinde: Leyla Küçükahmet (Ed.) Sınıf yönetimi (13. Bask1). (ss.1-16). Ankara: Pegem Akademi Yayıncılık.

Çapri, B., Balcı, A. ve Çelikkaleli, Ö. (2010). İlköğretim öğretmenlerinin sınıf içi istenmeyen davranışlara ilişkin görüşlerinin karşılaştırılması. Mersin Üniversitesi Eğitim Fakültesi Dergisi, 6(2), 89-102.

Çelik, V. (2008). Sinıf yönetimi. (4. Baskı). Ankara: Nobel Yayıncılık.

Döş, İ. (2010). Aday öğretmenlerin müfettişlik kavramına ilişkin metafor algıları. Gaziantep Üniversitesi Sosyal Bilimler Dergisi, 9(3), 607-629.

Egüz, Ş. ve Öntaş, T. (2018). Ortaokul öğrencilerinin "öğretmen” kavramına ilişkin kullandıkları metaforlar. MSKU Eğitim Fakültesi Dergisi, 5(1), 79-91. DOI: 10.21666/muefd.336181.

Ekici, G. ve Akdeniz, H. (2018). Öğretmen adaylarının “sınıfta disiplin sağlamak” kavramına ilişkin algılarının belirlenmesi: Bir metafor analizi çalışması. Dicle Üniversitesi Ziya Gökalp Eğitim Fakültesi Dergisi, 33, 26-37. DOI: 10.14582/DUZGEF.1854.

Ercan, L. (2012). Sınıfta istenmeyen davranışların yönetimi. İçinde: Leyla Küçükahmet (Ed.) Sinıf yönetimi (13. Bask1). (ss.183-210). Ankara: Pegem Akademi Yayıncılık.

Erden, M. (2014). Sinıf yönetimi (Yeni programla uyumlu genişletilmiş bask1, 2. Baskı). Ankara: Arkadaş Yayınları.

Fakioğlu Bağc1, H. (2012). İlkögretim Din Kültürü ve Ahlak Bilgisi Öğretmenlerinin Sinıf Yönetimi Yeterlikleri (Beykoz Örneği). (Yayınlanmamış Yüksek Lisans Tezi). Marmara Üniversitesi Sosyal Bilimler Enstitüsü, İstanbul. Erişim adresi: file:///C:/Users/HP/Downloads/317302\%20(3).pdf

Gökyer, N. ve Doğan, B. (2006). İstenmeyen öğrenci davranışları ve nedenlerine ilişkin yönetici ve öğretmen görüşleri. Fırat Üniversitesi Sosyal Bilimler Dergisi, 26(1), 93-105.

Gül, S. O. (2018). Sınıfta istenmeyen davranışların yönetimi. İçinde: Fatoş Silman ve Hasan Avcıoğlu (Ed.) Çăgdaş yaklaşımlarla sınıf yönetimi. (ss.97-129). Ankara: Eğiten Kitap Yayınları.

Gündüz, Y. (2001). Öğretmenlerin sınıf yönetimindeki yeterlilikleri. (Yayımlanmamış Yüksek Lisans Tezi). Yıldız Teknik Üniversitesi Sosyal Bilimler Enstitüsü, İstanbul. Erişim adresi: file:///C:/Users/HP/Downloads/112806.pdf

İlgar, L. (2000). Eğitim yönetimi okul yönetimi sınıf yönetimi. İstanbul: Beta Yayınları.

İra, N. (2016). İstenmeyen davranışlar ve önleme teknikleri. İçinde: İkram Çınar (Ed.) Sınıf yönetimi. (ss.165-177). Ankara: Eğiten Kitap Yayınları. 
Karateke, T. (2019). İmam Hatip Lisesi öğrencilerinin İmam Hatip Lisesi, meslek dersi öğretmeni ve idarecilerine ilişkin metaforik algıları. Cumhuriyet İlahiyat Dergisi, 23(3), 1235-1256.

Kars, Y. E. (2007). Din kültürü ve ahlak bilgisi ögrretmenlerinin kendi algllarına dayalı sinıf yönetimi yeterlikleri (Konak ilçesi örneği) (Yayımlanmamış Yüksek Lisans Tezi). Dokuz Eylül Üniversitesi Sosyal Bilimler Enstitüsü, İzmir. Erişim adresi: file:///C:/Users/HP/Downloads/209115\%20(3).pdf

Kocabıyık, O. (2015). Olgubilim ve gömülü kuram: bazı özellikler açısından karşılaştırma. Trakya Üniversitesi Eğitim Fakültesi Dergisi, 6(1), 55-66.

Koçak, A. ve Arun, Ö. (2006). İçerik analizi çalışmalarında örneklem sorunu. Selçuk İletişim, $4(3), 21-28$.

Korkmaz, İ. (2002). İstenmeyen davranışların önlenmesi. İçinde: Zeki Kaya (Ed.) Sınıf yönetim Ankara: Pegem Akademi Yayıncılık.

Küçüktepe, S. E. ve Gürültü, E. (2014). Öğretmenlerin yapılandırmacı öğretmen kavramına ilişkin algılarına yönelik metafor çalışması örneği. Abant İzzet Baysal Üniversitesi Ĕ̈itim Fakültesi Dergisi, 14(2), 282-305. DOI: 10.17240/aibuefd.2014.14.2-5000091540.

Lakoff, G. ve Johnson, M. (2005). Metaforlar: Hayat, anlam ve dil. Çev. G.Y. Demir. İstanbul: Paradigma Yayınları.

Martinez, M. A., Saulea, N. ve Huber, G. L. (2001). Metaphors as blueprints of thinking about teaching and learning. Teaching and Teacher Education, 17, 965-977.

Morgan, G. (1998). Yönetim ve örgüt teorilerinde metafor. İstanbul: Mess Yayınları.

Moore, K. D. (2003). Öğretim becerileri. Çev. Nizamettin Kaya. Ankara: Nobel Yayın Dağıtım.

Nalçacı, A. ve Bektaş, F. (2012). Öğretmen adaylarının okul kavramına ilişkin algıları. Ahi Evran Üniversitesi Kırşehir Ĕ̈itim Fakültesi Dergisi (KEFAD), 13(1), 239-258.

Özdemir, İ. E. (2004). Sınıf ortamında istenmeyen davranışlar. İçinde: Ş. Şule Erçetin, M. Çağatay Özdemir (Ed.) Sinıf yönetimi. Ankara: Asil Yayın Dağıtım.

Özer, B., Bozkurt, N. ve Tuncay, A. (2014). İstenmeyen öğrenci davranışları ve öğretmenlerin kullandıkları başa çıkma stratejileri. Turkish Journal of Educational Studies, 1(2), 152189.

Öztürk, B. (2002). Sınıfta istenmeyen davranışların önlenmesi ve giderilmesi. İçinde: Emin Karip (Ed.) Sinıf yönetimi. (ss.137-183). Ankara: Pegem Akademi Yayıncılık.

Özyürek, M. (1997). Sınıfta davranıs yönetimi. Ankara: Karatepe Yayınları.

Saban, A. (2004). Giriş düzeyindeki sınıf öğretmeni adaylarının "öğretmen” kavramına ilişkin ileri sürdükleri metaforlar. Türk Ĕgitim Bilimleri Dergisi, 2(2), 131-155.

Sarıtaş, M. (2000). Sınıf yönetimi ve disiplinle ilgili kurallar geliştirme. İçinde: Leyla Küçükahmet (Ed.) Sinıf Yönetiminde Yeni Yaklaşımlar. Ankara: Nobel Akademik Yayınc1lik.

Sarıtaş, M. (2006). Öğretmen adaylarının değerlendirmelerine göre sınıfta istenmeyen öğrenci davranışlarını değiştirmek ve düzeltmek amacıyla yararlanılan stratejiler. Uludă̆ Üniversitesi Ë̆itim Fakültesi Dergisi, 19(1), 167-187.

Sönmez, V. (1994). Program geliştirmede öğretmen el kitabı. Ankara: Pegem Akademi Yayınları. 
Şimşek, E. (2012). Din Kültürü ve Ahlak Bilgisi öğretmen adaylarının sınıf yönetimi stratejilerine yönelik görüşleri. Atatürk Üniversitesi Sosyal Bilimler Enstitüsü Dergisi, 16(3), 211-230.

Şişman, M. (2016). Türk eğitim sistemi ve okul yönetimi (10. Baskı). Ankara: Pegem Akademi Yayınc1lik.

Tortop, H. S. (2013). Öğretmen adaylarının üniversite hocası hakkındaki metaforları ve bir değerlendirme aracı olarak metafor. Yüksekögretim ve Bilim Dergisi/Journal of Higher Education and Science, 3(2), 153-160. DOI: 10.5961/jhes.2013.070.

Turan, S. (2018). Sınıf yönetiminin temelleri. İçinde: Mehmet Şişman ve Selahattin Turan (Ed.). Sinıf yönetimi. (14. Bask1). (ss.1-19). Ankara: Pegem Akademi Yayınları.

Turhan, M. ve Yaraş, Z. (2013). Öğretmen ve öğrencilerin öğretmen, disiplin, müdür, sınıf kuralları, ödül ve ceza kavramlarına ilişkin metafor algıları. Fırat Üniversitesi Sosyal Bilimler Dergisi, 23(1), 129-145.

Uçar, R. (2004). İlköğretim Okulları II. Kademedeki Din Kültürü ve Ahlak Bilgisi Ögretmenlerinin Sinıf Yönetimi Yeterlikleri (Kayseri il Merkezi Örneği). (Yayımlanmamış Yüksek Lisans Tezi). Erciyes Üniversitesi Sosyal Bilimler Enstitüsü, Kayseri. Erişim adresi: file:///C:/Users/HP/Downloads/146519\%20(3).pdf

Uyanık Balat, G. (2013). Sınıf yönetimi kavramı ve sınıf yönetimi modelleri. İçinde: G. Uyanık Balat ve H. Bilgin. (Ed.). Okul Öncesi Eğitimde Sinıf Yönetimi. (ss.1-11). Ankara: Eğiten Kitap Yayınları.

Uzun, S. ve Paliç, G. (2013). Sınıf öğretmenlerinin sınıf kavramına ilişkin sahip oldukları algıların metaforlar yardımıyla incelenmesi. Uşak Üniversitesi Sosyal Bilimler Dergisi, 6(4), 245-260. DOI: 10.12780/UUSBD211.

Yıldırım, A. ve Şimşek, H. (2013). Sosyal bilimlerde nitel araştırma yöntemleri. Ankara: Seçkin Yayınevi.

Y1lmaz, F., Göçen, S. ve Yılmaz, F. (2013). Öğretmen adaylarının öğretmen kavramına ilişkin algıları: bir metaforik çalışma. Mersin Üniversitesi Eğitim Fakültesi Dergisi, 9(1), 151164. DOI: $10.17860 /$ efd.49273.

Zengin, M. (2013). Din kültürü ve ahlak bilgisi öğretmenlerinin eğitim öğretim yeterlik algıları. Sakarya Üniversitesi İlahiyat Fakültesi Dergisi, 15(27), 1-28.

\section{EXTENDED ABSTRACT}

Class; It is a social group consisting of learners who have a common past, value judgments, and a common culture, and whose interests, abilities and intelligence levels are different from each other (Gökyer ve Doğan, 2016). According to Başar (2009), classroom management is the management of classroom life like an orchestra, the provision and maintenance of the necessary opportunities and processes, learning order, environment and rules to create an environment in which learning takes place. Classroom management approaches have been examined under two headings as traditional and contemporary approaches. Classroom management models, on the other hand, are stated as a reactive, preventive, and developmental holistic model. (Balay, 2003; Başar, 1996; Beytekin 2016; Çelik, 2008).

Religious education and training is a special field. Teachers of religious education should also have contemporary classroom management approaches and models. For this reason, this research wants to determine the perceptions of teachers who take religious education about classroom and classroom management through metaphors. Metaphor expressed as a way of 
thinking and seeing (Morgan, 1998) is defined as a thought material, a form of human understanding, not only a word figure but also a thought figure. (Lakoff ve Johnson, 2005).

In this study, which tries to determine teachers' perceptions about classroom and classroom management through metaphors in religious education, was used a phenomenological research design, one of the qualitative research designs. Phenomenological research (phenomenology) is a suitable research ground for studies that aim to investigate phenomena that are not entirely unfamiliar to us, and which we do not fully grasp. (Yıldırım ve Şimşek, 2013). The study group of this study, which tries to determine the perceptions of teachers of religious education on the concept of classroom and classroom management, consists of 105 teachers of religious education who are determined by purposeful sampling method on a voluntary basis. The data of the study were obtained using a semi-structured form. In this form "Class... like this. Because... "and Classroom management.... like this. Because... "answers were sought.

105 teachers developed 44 metaphors related to the classroom concept. The most frequently used metaphors by teachers when defining the concept of classroom are as follows: (1) garden, 23 teachers, $21.90 \%$. (2) scene, 9, 8.57\%. (3) family, 7, 6.66\%. (4) house, 7, 6.66\%. (5) beehive $4,3.80 \%$. (6) mirror $4,3.80 \%$. (7) soil 4, 3.80\%. The categories of metaphors produced on the concept of class are as follows: Class as a source of personal development, class as a source of love and trust, class as a shaping / future-oriented environment, class as a rich living space, class as a careful and intense study space, class as an enlightening environment, class as a source of information, source of discovery class as.

105 teachers developed 57 metaphors related to the concept of classroom management. The most used metaphors by teachers when defining the concept of classroom management are determined as follows: (1) conducting an orchestra 18, 17.14\%. (2) family management 8 , 7.61\%. (3) state administration 6, 5.71\%. (4) driving, 4, 3.80\%. (5) flower care, 4, 3.80\%. The categories of metaphors produced on classroom management are as follows: Classroom management as an art executed in harmony, classroom management as a guiding / training process, classroom management as a management / authority area, classroom management as a space of layout / control, classroom management as an area of struggle / troubleshooting, classroom management as a sensitive / risk-taking process.

When perceiving the classroom, teachers can use the garden, stage, home, family, etc. they used positive metaphors. Accordingly, it has been determined that teachers' positive perceptions about the classroom are much more dominant than their negative perceptions. The garden metaphor, which is the most used when defining the classroom, shows that the classroom is perceived as an environment that guides students' individual development. Accordingly, teachers are aware of their responsibility to direct students' individual development and lead them for this purpose. Likewise, metaphors such as family and home used to define the classroom show that teachers perceive the classroom as a warm / friendly environment. Accordingly, teachers see students as individuals from their own families and perceive them as their children. Stage metaphor is also among the frequently used metaphors. With this metaphor, teachers perceive the classroom as an environment that enhances students' creativity. With the beehive metaphor, teachers perceive the classroom as an environment that requires attention and care. Positive classroom perceptions of teachers will contribute positively to their success.

Teachers can manage classroom management, run an orchestra, run a family, run the state, drive a car, care for flowers, etc. they used positive metaphors. Accordingly, it was determined that teachers' positive perceptions about classroom management are much more dominant than their negative perceptions. The metaphor of conducting an orchestra, which is most used when defining classroom management, shows that teachers perceive classroom management as the harmonious management of different instruments. Accordingly, teachers 
perceive classroom management as the harmonious management of students whose interests, abilities and intelligence levels are different from each other. In addition, this definition should be considered as teachers' awareness of the necessity of using contemporary classroom management approaches in accordance with the individual differences of students in a rich classroom environment. With the metaphor of family management, classroom management is perceived as the necessity of treating students with compassion and compassion in a classroom environment like a parent. The metaphor of state administration shows that teachers also see classroom management as an element of authority. Accordingly, teachers also attach importance to the establishment of the necessary rules in the classroom environment, the establishment of order and the active participation of the student in the rule-making process. With the flower care metaphor, teachers perceive classroom management as a guiding / nurturing process. According to this, teachers state that they care about a contemporary understanding of classroom management that can guide their students and mediate their training process. Accordingly, teachers' positive perceptions of classroom management will contribute positively to teachers' success in classroom management.

According to the research results, the following recommendations have been developed:

- Teachers of religious education should be given information about metaphor, forming metaphors, and the importance of metaphor.

- Teachers of religious education should use metaphors in teaching abstract subjects / concepts of religious education courses.

- Studies using different methods can be conducted to reveal the classroom and classroom management perceptions of religious education teachers. The findings obtained can be compared with the findings of this research.

- Similar studies can be conducted to determine the perceptions of religious education teachers and teachers from other disciplines about classroom and classroom management. Comparisons can be made between the findings of these studies and new research findings.

- A similar research can be done with candidate teachers of religious education. Comparisons can be made between prospective teachers and teachers' perceptions of classroom and classroom management.

- Similar studies can be conducted between candidate religious education teachers and prospective teachers studying at education faculties. Their perceptions of class and classroom management can be compared. 